\title{
Natural Killer T Cells and Mucosal- Associated Invariant T Cells in Lung Infections
}

\author{
François Trottein ${ }^{1,2,3,4,5 *}$ and Christophe Paget ${ }^{6,7}$ \\ 'Univ. Lille, U1019 - UMR 8204 - CIIL - Centre d'Infection et d'Immunité de Lille, Lille, France, ${ }^{2}$ Centre National de la \\ Recherche Scientifique, UMR 8204, Lille, France, ${ }^{3}$ Institut National de la Santé et de la Recherche Médicale U1019, Lille, \\ France, ${ }^{4}$ Centre Hospitalier Universitaire de Lille, Lille, France, ${ }^{5}$ Institut Pasteur de Lille, Lille, France, ${ }^{6}$ Institut National \\ de la Santé et de la Recherche Médicale U1100, Centre d'Etude des Pathologies Respiratoires (CEPR), Tours, France, \\ ${ }^{7}$ Université de Tours, Tours, France
}

The immune system has been traditionally divided into two arms called innate and adaptive immunity. Typically, innate immunity refers to rapid defense mechanisms that set in motion within minutes to hours following an insult. Conversely, the adaptive immune response emerges after several days and relies on the innate immune response for its initiation and subsequent outcome. However, the recent discovery of immune cells displaying merged properties indicates that this distinction is not mutually exclusive. These populations that span the innate-adaptive border of immunity comprise, among others, CD1d-restricted natural killer T cells and MR1-restricted mucosal-associated invariant T cells. These cells have the unique ability to swiftly activate in response to non-peptidic antigens through their T cell receptor and/or to activating cytokines in order to modulate many aspects of the immune response. Despite they recirculate all through the body via the bloodstream, these cells mainly establish residency at barrier sites including lungs. Here, we discuss the current knowledge into the biology of these cells during lung (viral and bacterial) infections including activation mechanisms and functions. We also discuss future strategies targeting these cell types to optimize immune responses against respiratory pathogens.

\section{Keywords: natural killer T cells, mucosal-associated invariant T cells, mucosal immunity, infection, lung, bacteria,} viruses, immunotherapy

The respiratory tract constitutes one of the major sites of entry for pathogens. According to the vital nature of this organ, immune responses in the lung mucosa need to be finely regulated in a time- and strength-dependent manner. First, microbial-derived signals have to be rapidly integrated by the immune system in order to establish an efficient response that will allow containment and elimination of the pathogens. However, if not properly regulated, this inflammatory response can also turn into immunopathology leading to extensive tissue damages and organ failure with devastating outcomes for the host. Thus, the enrichment within the lung mucosa for cells endowed with potent immunoregulatory functions is paramount to combat infections as well as to maintain

Abbreviations: TCR, T cell receptor; MHC, major histocompatibility complex; Ag, antigen; NKT, natural killer T; MAIT, mucosal-associated invariant T; GSL, glycosphingolipids; $\alpha$-GalCer, $\alpha$-galactosylceramide; PLZF, pro-myelocytic leukemia zinc finger; Tg, transgenic; DC, dendritic cell; BCG, bacillus Calmette-Guérin; IAV, influenza A virus; Ab, antibody; WT, wild-type; CAR, chimeric Ag receptor. 
tissue functions and integrity. Among these cells, the family of unconventional $\alpha \beta \mathrm{T}$ lymphocytes recently emerged as central player in mucosal immunity.

These unconventional $\alpha \beta$ T cells differ from conventional $\alpha \beta$ $\mathrm{T}$ lymphocytes in many respects. After thymic egress, unconventional $\alpha \beta$ T cells are readily capable of cytokine/chemokine secretion and cytolysis. Thus, unconventional $\alpha \beta$ T cells occupy a unique niche in the immune system (spanning the innateadaptive border of immunity). In contrast to its huge diversity in conventional $\mathrm{T}$ cells, the $\mathrm{T}$ cell receptor (TCR) repertoire of unconventional $\alpha \beta$ T cells is fairly conserved and presents a limited number of $\mathrm{V}(\mathrm{D}) \mathrm{J}$ rearrangements. In addition, unlike conventional $\mathrm{T}$ cells that are restricted to the polymorphic major histocompatibility complex (MHC) class I and MHC class II molecules; unconventional $\alpha \beta \mathrm{T}$ cells recognize conserved antigens (Ags) [including (glyco)lipids, small metabolites, and modified-peptides] presented by the quasi-monomorphic MHC class Ib (e.g., HLA-E/Qa-1b, H2-M3) and MHC class-I like (e.g., group 1 and 2CD1, MR1) molecules.

Due to their quite low representation in rodents and the absence of specific tools to analyze them, unconventional $\alpha \beta$ $\mathrm{T}$ cells have been overlooked by the scientific community for a long time. Thanks to the development of biological tools (e.g., gene-targeted mice and tetramers), the interest in understanding the functions and role of unconventional $\mathrm{T}$ cells in tissue homeostasis and diseases has tremendously grown over the last decades. As a result, the current literature quickly expands to the extent that unconventional $\mathrm{T}$ cells are now highly regarded by clinicians as attractive targets for future innovative cell-based immunotherapies. Here, we focused our attention on two major subsets of "innate-like" unconventional $\alpha \beta$ T cells namely CD1d-restricted natural killer T (NKT) and MR1-restricted mucosal-associated invariant T (MAIT) cells. We discuss the recent advances in the functions of these cells during lung infections in mice and humans as well as the potential therapeutic opportunities based on harnessing the biology of these cells.

\section{GENERAL FEATURES OF CD1d- AND MR1-RESTRICTED T CELLS}

CD1d- and MR1-restricted T cells represent a heterogeneous population of cells (Table 1). In this section, we review the general features and biological tools available to analyze these particular subsets.

\section{CD1d-Restricted T Cells}

Natural killer T cells were the first member of the CD1d-restricted $\mathrm{T}$ cell family to be described. Originally, NKT cells were named after pioneer studies that observed the co-expression of-initially thought-NK cell-specific markers on a T cell subset $(1,2)$.

TABLE 1 | Classification and characteristics of CD1d-and MR1-restricted T cells.

\begin{tabular}{|c|c|c|c|c|}
\hline Family & Subsets & TCR repertoire & TCR ligands & Functions \\
\hline \multirow[t]{10}{*}{$\begin{array}{l}\text { CD1d- } \\
\text { restricted } \\
\text { T cells }\end{array}$} & \multirow[t]{5}{*}{$\begin{array}{l}\text { Type I natural killer } \\
\mathrm{T}(\mathrm{NKT}) \text { cells }\end{array}$} & $\begin{array}{l}\text { Mouse: J } \alpha 14-V_{\alpha} 18 \text { with } \\
\vee \beta 8, \vee \beta 7 \text { and } \vee \beta 2 \text { bias }\end{array}$ & $\begin{array}{l}\text { Of either host or } \\
\text { microbial origins }\end{array}$ & $\begin{array}{l}\text { Cytokine secretion: NKT1: IFN- } \gamma \text {, IL-2, TNF- } \alpha \text {; NKT2: IL-4, IL-9, } \\
\text { IL-13; NKT17: IL-17, IL-21, IL-22; NKT10: IL-10; NKT FH-like: } \\
\text { IL-5, IL-6, IL-21 }\end{array}$ \\
\hline & & \multirow{4}{*}{$\begin{array}{l}\text { Human: } \vee \alpha 24-J \alpha 18 \text { with } \\
\text { strong } \vee \beta 11 \text { bias }\end{array}$} & $\alpha$-GalCer & \multirow[t]{4}{*}{ Cytotoxic capacity: perforin, granzyme } \\
\hline & & & $\alpha$-GSL & \\
\hline & & & $\beta$-GSL & \\
\hline & & & $\alpha-G \mid c D A G$ & \\
\hline & \multirow[t]{2}{*}{ Type II NKT cells } & $\begin{array}{l}\text { Mouse: diverse with } \\
\text { oligoclonal } \vee \alpha 3.2-J \alpha 9 / \mathrm{N} \beta 8 \\
\text { and } V \alpha 8 / \mathrm{N} \beta 8\end{array}$ & $\begin{array}{l}\text { Of either host or } \\
\text { microbial origins }\end{array}$ & $\begin{array}{l}\text { Cytokine secretion: } T_{\mathrm{H} 1} \text {-related: IFN- } \gamma \text {, IL-2; } T_{\mathrm{H} 2} \text {-related: IL-4, } \\
\text { IL-13; } T_{\mathrm{H} 17} \text {-related: IL-17; } T_{\mathrm{HO}} \text {-related: IL-10; } \mathrm{T}_{\mathrm{FH}} \text {-related: IL-5, } \\
\text { IL-6, IL-17 }\end{array}$ \\
\hline & & Human: diverse? & Sulfatide, LPC, LPE, and PG & Cytotoxic capacity: perforin, granzyme \\
\hline & \multirow[t]{3}{*}{$\begin{array}{l}\text { Other CD1d- } \\
\text { restricted cells }\end{array}$} & $\begin{array}{l}\text { With } \alpha \beta \text { TCR } \\
\text { Mouse: V } \alpha 10-J \alpha 50 / N \beta 8 \\
\text { (Type la NKT) } \\
\text { Human: V } \alpha 24^{-} \text {N } \beta 11^{ \pm}\end{array}$ & $\begin{array}{l}\alpha \text {-GalCer and microbial- } \\
\text { derived lipids }\end{array}$ & $\begin{array}{l}\text { Cytokine secretion: IFN- } \gamma, \mathrm{IL}-4, \mathrm{IL}-13 \text { and } \mathrm{IL}-17 \\
\text { Cytotoxicity? }\end{array}$ \\
\hline & & $\begin{array}{l}\text { With } \gamma \delta \mathrm{TCR} \\
\text { Mouse: diverse including } \mathrm{V} \delta 4^{+} \\
\text {Human: } \vee \delta 1^{+}\end{array}$ & $\begin{array}{l}\text { m: Cardiolipin } \\
\text { h: } \alpha \text {-GalCer and Sulfatide }\end{array}$ & \multirow[t]{2}{*}{$\begin{array}{l}\text { Cytokine secretion: IFN- } \gamma \text { and IL-4 } \\
\text { Cytotoxicity? }\end{array}$} \\
\hline & & $\begin{array}{l}\text { With } \delta / \alpha \beta \text { TCR } \\
\text { V } \delta 1^{+-} J \alpha-C \alpha / \beta \beta\end{array}$ & $\alpha$-GalCer and analogs & \\
\hline \multirow{5}{*}{$\begin{array}{l}\text { Mr1-restricted } \\
\text { T cells }\end{array}$} & \multirow[t]{2}{*}{ MAIT cells } & Mouse: $V_{\alpha 19} 19 \alpha 33$ & \multirow{2}{*}{$\begin{array}{l}\text { Riboflavin derivatives (including } \\
\text { uracils and lumazines) }\end{array}$} & Cytokine secretion: IFN- $\gamma, \mathrm{TNF}-\alpha$ and IL-17A \\
\hline & & Human: V $\alpha 7.2-J \alpha 33$ & & Cytotoxic capacity \\
\hline & \multirow{3}{*}{$\begin{array}{l}\text { Atypical Mr1- } \\
\text { restricted T cells }\end{array}$} & \multirow[t]{2}{*}{ Only reported in humans } & \multirow{3}{*}{$\begin{array}{l}\text { Diverse metabolites? } \\
\text { including pterins }\end{array}$} & Cytokine secretion: $\mathrm{T}_{\mathrm{H}^{-}}, \mathrm{T}_{\mathrm{H} 2^{-}}$, and $\mathrm{T}_{\mathrm{H} 17^{-}}$-related cytokines \\
\hline & & & & Highly variable between clones \\
\hline & & Diverse TCR repertoire & & Cytotoxicity? \\
\hline
\end{tabular}

$\alpha$-GalCer, $\alpha$-galactosylceramide; GSL, glycosphingolipid; $\alpha$-GICDAG, $\alpha$-monoglucosyldiacylglycerol; LPC, lysophosphatidylcholine; LPE, Iysophosphatidylethanolamine; PG, phosphatidylglycerol. 
Nowadays, this definition is obsolete since some NKT subsets do not necessarily express NK cell-related molecules $(3,4)$. By definition, CD1d-restricted $\mathrm{T}$ cells comprise the heterogeneous family of $\mathrm{T}$ cells that are restricted to the CD1d molecule [for reviews, see Ref. (5-7)]. Specifically, CD1d-restricted T cells can be further segregated into three groups called type I (or "invariant") NKT, type II (or "variant") NKT, and "others" CD1d-restricted T cells regarding their Ag specificity and TCR usage (8).

\section{Type I NKT Cells}

Type I NKT cells are the most characterized population of CD1drestricted T cells. Type I NKT cells express a semi-invariant TCR composed of an invariant TCR $\alpha$-chain (V $\alpha 14-J \alpha 18$ in mice and $\mathrm{V} \alpha 24$-J $\alpha 18$ in humans) paired with a limited set of TCR $\beta$-chains $(5,7)$. Type I NKT cells are also defined by their strong capacity to react through their TCR to the glycosphingolipid (GSL) alpha-galactosylceramide ( $\alpha$-GalCer) once inserted into the CD1d molecule (9). In addition, the type I NKT TCR has been shown to recognize a wide range of microbial-derived lipids $(6,10-12)$, which allows them to specifically respond in a broad set of infectious diseases. Of importance, type I NKT cells can also activate in response to a wide array of cytokines including IL-12, IL-1 $\beta$, IL-18, IL-23, and IFN- $\beta$ (13-15).

Type I NKT cells are relatively abundant in mice in which they populate both lymphoid and non-lymphoid tissues. On average, type I NKT cells represent $1-3 \%$ of the T cell pool and can account for up to $20-30 \%$ of total T cells in specific niches such as the liver (8). In sharp contrast, type I NKT cells are far less frequent in humans (100-fold lower frequencies at similar locations) at the exception of the omentum where they can represent $10-20 \%$ of total $\mathrm{CD}^{+}$cells (16). Of note, type I NKT cell subsets can be defined regarding the pattern of cytokines produced including NKT1 [IFN- $\gamma$-producing, pro-myelocytic leukemia zinc finger (PLZF) ${ }^{\text {low }} /$ T-bet $^{+}$, NKT2 (IL-4-producing, PLZF $^{\text {high }} /$ T-bet $^{-}$), and NKT17 (IL-17-producing, ROR $\gamma \mathrm{t}^{+}$) subset $(17,18)$.

Upon activation, type I NKT cells can rapidly produce substantial amounts of multiple chemokines (including CCL2, CCL3, CCL4, CCL5, CCL11, and CXCL8) and cytokines such as TNF- $\alpha$, IFN- $\gamma$, IL-4, IL-5, IL-10, IL-13, IL-17, IL-21, IL-22, and GM-CSF (19). This ability to produce a wide range of chemokines and cytokines (with sometimes opposite functions) depends on the nature of the stimuli (e.g., Ags and/or activating cytokines) as well as the cell subset triggered. Through this property, type I NKT cells have been shown to interact with as well as to influence the functions of numerous immune populations including neutrophils, dendritic cells (DCs), macrophages, NK cells, $\gamma \delta \mathrm{T}$ cells, B and conventional T cells (20-28). In addition, type I NKT cells are capable to directly kill transformed and virally infected cells $(28,29)$.

\section{Type II NKT Cells}

Conversely, type II NKT cells represent a much broader family engulfing all other CD1d-restricted $\alpha \beta$ T cells that react to lipids, but not to $\alpha$-GalCer $(8,30,31)$. Thus, type II NKT cells express a more diverse TCR repertoire. For instance, in mice, type II NKT cells use V $\alpha 1, \mathrm{~V} \alpha 3.2, \mathrm{~V} \alpha 4, \mathrm{~V} \alpha 8$, or $\mathrm{V} \alpha 11$ TCR $\alpha$-chains paired with $\mathrm{V} \beta 3, \mathrm{~V} \beta 5, \mathrm{~V} \beta 8$, or $\mathrm{V} \beta 11$ TCR $\beta$-chains and also comprise oligoclonal $\mathrm{V} \alpha 3.2-\mathrm{J} \alpha 9 / \mathrm{V} \beta 9$ and $\mathrm{V} \alpha 8 / \mathrm{V} \beta 8$ subsets (30). The TCR usage of type II NKT cells in humans is far less understood. However, type II NKT cells seem to be more abundant than type I NKT cells in humans (32). In line with their TCR diversity, type II NKT cells recognize Ags of various nature and origin (mammalian and microbial) including glycolipids (lyso)phospholipids and non-lipidic small molecules (33-38).

Due to the lack of specific tools to investigate their entire pool, the functions of type II NKT cells have mainly been proposed indirectly by comparing the phenotypes observed in J 18 - (which lack type INKT cells) versus CD1d-deficient (which lack both type I and type II NKT cells) mice in various settings. Despite being informative, this strategy is not without concerns for several reasons. First, this way of analysis imposes to speculate that NKT cell subsets do not regulate the functions of each other. A recent report also indicates that $C d 1 d^{-/-}$mice present a significant enrichment for mature MAIT cells in the thymus and spleen that could account for the phenotype observed in these mice (39). In addition, the original $J \alpha 18^{-/-}$ mouse line presented a severely impaired expression of many TRAJ segments (40). However, the recent generation of new mouse lines with specific deletion of TRAJ18 $(41,42)$ will allow to validate or not the pioneer experiments. Nevertheless, type II NKT cells appear to share conserved phenotypic and functional similarities with type I NKT cells including an effector memory phenotype, cytotoxicity, and secretion of numerous cytokines/ chemokines $(8,31,43,44)$. Thus, they have been proposed to participate in antimicrobial responses, auto-immunity, and cancer $(31,43,44)$.

\section{Other CD1d-Restricted T Cells}

Type I NKT and type II NKT cells account for the vast majority of the CD1d-restricted T cell pool. However, the recent literature indicates that the diversity of this family is much more complex than initially believed (45). For instance, the identification of a minute population of CD1d/ $\alpha-G$ alCer tetramer-positive cells in $J \alpha 18^{-/-}$mice brought a new layer of complexity in the definition of NKT cells (46). These cells expressed a semi-invariant V $\alpha 10-J \alpha 50$ TCR with minimal conservation in the amino acid sequence of the TCR $\alpha$ chain expressed on type I V $\alpha 14-\mathrm{J} \alpha 18 \mathrm{NKT}$ cells (46). Interestingly, $\alpha$-GalCer-reactive non-type I V $\alpha 24^{+}-\mathrm{J} \alpha 18^{+} / \mathrm{V} \beta 11^{+} \mathrm{NKT}$ cells can also be observed in humans (47). This includes $\mathrm{V} \alpha 24^{-}$ $\mathrm{J} \alpha 18^{+} / \mathrm{V} \beta 11^{+}$subset with public TCR repertoires and diverse populations of $\mathrm{V} \alpha 24^{-} \mathrm{J} \alpha 18^{-} / \mathrm{V} \beta 11^{-}$with private repertoires (47). More surprisingly, some human $\gamma \delta \mathrm{T}$ cell subsets can react to lipids (e.g., $\alpha$-GalCer, sulfatide, andphosphatidylethanolamine) in the context of CD1d (48-51). Existence of CD1dreactive $\gamma \delta$ T cells has also been proposed in mice (52). Last, an unusual population of T cells bearing a hybrid $\delta / \alpha \beta$ TCR was shown to recognize CD1d/ $\alpha-$ GalCer complex (53). Further investigations are clearly required to evaluate the biological relevance of these rare subsets and to understand why they have been conserved across species. Altogether, this new literature highlights the huge-probably still expanding-diversity of the CD1d-restricted $\mathrm{T}$ cell family. 


\section{MR1-Restricted T Cells}

Mucosal-associated invariant $\mathrm{T}$ cells probably represent the main subset of $\mathrm{T}$ cells restricted to the MHC class I-related molecule, MR1 $(54,55)$. MAIT cells were initially named after their observation in the gut lamina propria of humans and mice (54). Despite their characteristics of tissue-resident memory $\mathrm{T}$ cells at barrier sites, MAIT cells can also populate lymphoid tissues and non-lymphoid organs (8) such as the liver $(56,57)$. In addition, MAIT cells circulate through the bloodstream where they can represent up to $10 \%$ of the human T cell compartment. On the contrary, MAIT cells are relatively rare in standard laboratory mouse strains $(55,58)$.

Mucosal-associated invariant $\mathrm{T}$ cells are characterized by the expression of a semi-invariant TCR composed of a canonical $\mathrm{TCR} \alpha$ chain (V $\alpha 19-\mathrm{J} \alpha 33$ in mice and $\mathrm{V} \alpha 7.2-\mathrm{J} \alpha 33$ in humans) associated with a restricted set of V $\beta$ segments $(54,55,58,59)$. Several subsets of human and mouse MAIT cells have recently been identified, including MAIT cell precursors $(39,60)$ and non-MAIT mature human MR1-restricted T cells using diverse $\alpha \beta$ TCR (61-63) that may have specific functions such as tumor Ag recognition.

Through their TCR, MAIT cells recognize small intermediate metabolites from the riboflavin (vitamin B2) pathway of bacteria (64). The first defined Ags were microbial pterin-like compounds presenting a ribityl moiety (64). In addition, the nonenzymatic reaction between a riboflavin precursor(5-amino6-D-ribitylaminouracil) and small aldehydes (glyoxal/methylglyoxal) of both microbial and host origin generates two instable forms namely 5-(2-oxoethylideneamino)-6-D-ribitylaminouracil and 5-(2-oxopropylideneamino)-6-D-ribitylaminouracil (65). These two molecules represent potent Ags that are able to bind into MR1 and activate mouse and human MAIT cells $(65,66)$.

These discoveries subsequently enabled the development of mouse and human MR1 tetramers loaded with MAIT cell Ags that represented a major breakthrough in the investigation of MAIT cell biology including development, phenotype, and functions $(39,58,67)$. Reminiscent with NKT cell biology, MAIT cells can respond to TCR signals and/or to various activating cytokines including IL-12, IL-1 $\beta$, IL-18, and IL-23 $(56,68,69)$. Upon activation, MAIT cells produce large amounts of Th1- and Th17related cytokines such as IFN- $\gamma$, TNF- $\alpha$, IL-17A, and IL-22 (70). Additionally, MAIT cells are capable of efficiently kill bacteriainfected cells $(71,72)$.

Due to their scarce representation in common laboratory mouse strains, understanding MAIT cell biology is challenging by comparing wild-type (WT) and $\mathrm{Mr}^{-/-}$mice. To better assess their functions, transgenic mice $\left(V \alpha 19 i \mathrm{Tg} \times \mathrm{C}^{-/-}\right)$displaying high content of MAIT cells have been developed (73). However, the use of these mice is not without concerns since MR1 tetramer-positive cells can still be detected in Vo19i TCR transgenic ( $\mathrm{Tg}$ ) mice that lack MR1 (58). In addition, a certain abnormality in MAIT cells have been reported in these Tg mice (67). Nevertheless, MAIT cells can be found at high frequencies in unusual inbred mouse strains such as Mus musculus castaneus (CAST mice) (74). Interestingly, the reason for this MAIT phenotype in CAST mice relies on a single locus located on chromosome 14. Thus, a congenic mouse presenting a high level of MAIT cells (20× compared to classical C57BL/6) on a C57BL/6 background (named B6-MAIT ${ }^{\mathrm{CAST}}$ ) was generated (74) and will be likely to be helpful to investigate the functions of MAIT cells.

Given their cytokine profile and cytotoxic capacity, MAIT cells intuitively emerged as cell subsets specialized in host defense against bacteria. However, recent evidences indicate that MAIT cells get activated in many pathological situations such as acute and chronic viral infections $(68,75-78)$, solid cancers and hematological malignancies (79-82), as well as many inflammatory disorders including type I and type II diabetes $(83,84)$, inflammatory bowel disease $(85,86)$, graft-versus-host disease $(87)$, chronic obstructive pulmonary disease $(88,89)$, and multiple sclerosis $(90,91)$.

\section{LUNG CD1d-RESTRICTED NKT CELLS AND MR1-RESTRICTED MAIT CELLS IN HEALTH}

\section{CD1d-Restricted NKT Cells}

In mice, type I NKT cells account for around $2-5 \%$ of lungresident $\mathrm{T}$ lymphocytes. Lung type I NKT cells are mainly resident either as marginated cells within the vasculature or located in the lung interstitial parenchyma $(92,93)$. The lungs are particularly enriched for NKT17 cells compared to the vast majority of tissues (3). Interestingly, type I NKT cell location in the lung tissue is strongly dependent on the subsets. While NKT1 and NKT2 cells are predominantly found in the vasculature, NKT17 cells are at frontline within the lung parenchyma $(93,94)$. However, the factors that regulate their homing and homeostasis in the lung tissue are yet to be defined. Of note, microbiota seems to regulate lung type I NKT cell homeostasis since germ-free mice display an increase frequency of type I NKT cells, which is dependent on hypermethylation and increase levels of CXCL16 (95).

\section{MR1-Restricted MAIT Cells}

Mucosal-associated invariant $\mathrm{T}$ cells are also present in the lung tissue of mice in which they account for approximately 2 and $0.3 \%$ of resident $\mathrm{T}$ lymphocytes in $\mathrm{C} 57 \mathrm{Bl} / 6 \mathrm{~J}$ and $\mathrm{BALB} / \mathrm{c}$, respectively (67). Akin to NKT cells, lung MAIT cells predominantly display a phenotype of IL-17-producing cells defined by high expression of IL-7R $\alpha$ and IL-18R1 and the lack of NK1.1 expression (67). In line, stimulation of purified lung MAIT cells of naive mice induced strong IL-17A production but little IFN- $\gamma$ (67). In addition, they present a phenotype of effector memory cells (CD44 $\left.4^{\text {high }} \mathrm{CD} 62 \mathrm{~L}^{\text {low }}\right)$. The precise pulmonary niches of MAIT cells have not been determined, so far, but should be revealed soon, for instance, using antibody (Ab)-mediated in vivo labeling. How lung MAIT cells rely on commensal bacteria is currently unknown; however, there is a severe impairment in MAIT cells in the thymus, spleen, and gut of germ-free mice $(39,54)$. While NKT cells and MAIT cells appear to patrol the lungs in the steady state, their contribution to lung physiology and tissue integrity remains to be determined. 


\section{CD1d-RESTRICTED NKT CELLS AND MR1-RESTRICTED MAIT CELLS IN LUNG INFECTIONS}

A large body of evidence in both preclinical and clinical settings has recently suggested a key role for both NKT cells and MAIT cells in host response against lung pathogens (Table 2). Here, we compared the mode of activation and functions of NKT cells and MAIT cells in infectious respiratory diseases. We focused our interest on pathogens that provide data for both populations.

\section{Mycobacteria}

Mycobacteria are the causative agents of tuberculosis (TB) due to a group of closely related species including Mycobacterium tuberculosis, Mycobacterium bovis, M. microti, and M. africanum. More than a billion of people have died of TB during the last three centuries. Nowadays, TB remains the major cause of death due to infection, causing an estimation of 10 million new cases and $\sim 2$ millions of fatalities per year worldwide (121). In addition, one-quarter to one-third of the global human population is latently infected $(122,123)$, constituting a large reservoir for future spread of active TB. TB control mainly relies on a 100-year-old vaccine [Bacillus Calmette-Guérin (BCG)] (124) that saved the lives of many children without impacting on $\mathrm{TB}$ prevalence. In addition, the emergence of resistances for antituberculosis drugs, developed several decades ago, becomes worrying (125).

\section{NKT Cells}

The role of NKT cells during Mycobacterium infection has been extensively studied in preclinical models $(96-98,126)$. Early type I NKT cell activation (IFN- $\gamma$ release and cytotoxicity) has been reported during M. bovis BCG and M. tuberculosis infections $(96,99,126)$. In addition, type I NKT cells can also exert antimycobacterial effector function in vitro through the secretion of GM-CSF (127). The mechanisms that drive type I NKT cell activation have been shown to rely on both adaptive and innate cues such as CD1d-mediated Ag recognition and the activating cytokines IL-12 and IL-18 (97, 126). Several mycobacterial-derived lipids such as phosphatidylglycerol, cardiolipin, or phosphatidylinositol activate type II but not type I NKT cells (35) even if an early study has suggested CD1ddependent antigenic properties for phosphatidylinositol mannoside on type I NKT cells (128). Despite their early activation during mycobacterial infections, type I NKT cells do not appear to have a critical role in the control of TB (100-104) despite some controversial results have been reported regarding granuloma formation $(96,105,126)$. Akin to $J \alpha 18^{-/-}$mice, CD1ddeficient mice did not significantly differ in their susceptibility to mycobacterial infection compared to control mice (106). This suggests that neither type I nor type II NKT cells play a cardinal role in TB outcome in mice.

Several clinical reports indicated that patients with active TB present reduced levels of circulating NKT cells compared to patients with latent forms (129-134). However, NKT cells from patients with active TB present an activated phenotype and can secrete high amounts of IFN- $\gamma(129,135)$. Of note, NKT cell activation in TB patients leads to PD-1 expression at cell surface and subsequent apoptosis of IFN- $\gamma$-producing NKT cells, a phenomenon that can be reversed through PD-1 blockade $(136,137)$. Human NKT cells have also been shown to exert direct bactericidal effects on $M$. tuberculosis-infected macrophages (126). In addition, some NKT cells from pleural effusion of TB patients present characteristics of $\mathrm{T}_{\mathrm{FH}}$-like cells (138). Thus, it is possible that $\mathrm{T}_{\mathrm{FH}}$-like NKT cells produce IL-21 to participate in local B cell response against $M$. tuberculosis (138).

Although preclinical models do not point toward a key role for NKT cells in TB, their rapid response and immunoregulatory functions poised them as an interesting target for cell-based therapies. In line, exogenous activation of type I NKT cells with $\alpha$-GalCer (alone or in combination with classical chemotherapy) protected mice from lethal TB $(96,99,139,140)$. The molecular determinants that drive this protective effect are not fully understood but are likely to rely on enhanced innate response such as IFN- $\gamma$ production and cytotoxicity. Moreover, $\alpha$-GalCer (or analogs) incorporation into BCG vaccine enhances immune responses in mice by modulating $\mathrm{T}$ cell priming via type $\mathrm{I}$ NKT cell activation (141). $\alpha$-GalCer can also exert adjuvant effect on TB vaccines using the sublingual route by enhancing Ag-specific IFN- $\gamma$-producing $\mathrm{T}$ cells (142). In addition to its primary application as a vaccine for TB prevention, epidemiological studies have suggested that $B C G$ vaccination may prevent IgE-mediated allergic diseases in mice and humans $(143,144)$. Interestingly, the BCG-mediated IgE response suppression appears to be dependent on IL-21 secretion by type I NKT cells that mediates specific apoptosis of IgE-expressing B cells (145).

\section{MAIT Cells}

The role of MAIT cells in preclinical model of TB has been explored. Mouse MAIT cells can inhibit intracellular growth of M. bovis BCG in macrophages (107). This effect relies on MR1and IL-12-dependent IFN- $\gamma$ secretion by MAIT cells (107). Interestingly, upon BCG infection at low dose, $\mathrm{Mr}^{-/-}$mice displayed a higher bacterial burden in the lung during the early course of infection compared to MAIT cell-proficient mice. However, similar bacterial loads were observed at later stage of infection (107) suggesting an important role for MAIT cells in early control of bacterial growth although inefficient to prevent long-lasting establishment of the bacteria in the lung tissue. The role of MAIT cells in controlling mycobacterial infection has also been evaluated using $V \alpha 19 i \mathrm{Tg}$ mice (69). Upon intravenous injection of M. abscessus, $V \alpha 19 i \mathrm{Tg} \times \mathrm{MrI}^{-/-}$mice displayed slightly but significant higher bacterial loads than their $\mathrm{MrI}^{+/+}$ littermates (69). Despite having an increased proportion of MAIT cells, it is important to mention that $V \alpha 19 i \mathrm{Tg} \times \mathrm{Mr}^{+/+}$ mice have a comparable bacterial burden compared to WT mice (69). Thus, MAIT cells play a limited protective role in the early course of mycobacterial infections.

Akin to NKT cells, clinical studies in patients with active TB indicated a striking decrease in frequency of circulating MAIT cells compared to healthy controls $(69,71,146)$. This strong reduction is paralleled with an enrichment of MAIT cells 
TABLE 2 | In vivo role of natural killer T (NKT) cells and mucosal-associated invariant T (MAIT) cells in lung infections.

\begin{tabular}{|c|c|c|c|c|c|c|}
\hline Microorganisms & Subsets & $\begin{array}{l}\text { Cytokine } \\
\text { produced }\end{array}$ & $\begin{array}{l}\text { Activation } \\
\text { mechanisms }\end{array}$ & Functions & Phenotype in mouse lines & Reference \\
\hline \multirow{7}{*}{$\begin{array}{l}\text { Mycobacterial } \\
\text { infections }\end{array}$} & Type I NKT & $\mathrm{IFN}-\gamma$ & CD1d- and cytokine- & Not essential for host defense & No differences in survival or & $(96-106)$ \\
\hline & & & mediated (IL-12 and IL-18) & - & bacterial loads using $J \alpha 18^{-/-}$ & \\
\hline & & & & $\begin{array}{l}\text { Control granuloma formation } \\
\text { (controversial) }\end{array}$ & & \\
\hline & MAIT & $\mathrm{IFN}-\gamma$ & - & $\begin{array}{l}\text { Early but not late control } \\
\text { of bacterial outgrowth }\end{array}$ & $\begin{array}{l}\text { Increased bacterial burden } \\
\text { in } V_{\alpha} 19 i \times \mathrm{Mr}^{-1-} \text { compared } \\
\text { to } \mathrm{V}_{\alpha 1} 19 i \times \mathrm{Mr}^{+/+} \text {mice }\end{array}$ & $(69,107)$ \\
\hline & & IL-17A & & & - & \\
\hline & & (indirect & & & Increased bacterial loads in & \\
\hline & & evidences) & & & $\begin{array}{l}\mathrm{Mr}^{-/-} \text {mice compared to } \\
\text { wild-type }(\mathrm{WT}) \text { (only observed } \\
\text { at early stage) }\end{array}$ & \\
\hline \multirow[t]{7}{*}{$\begin{array}{l}\text { Francisella. } \\
\text { tularensis } \\
\text { (LVS strain) }\end{array}$} & \multirow[t]{3}{*}{$\begin{array}{l}\text { Type I and } \\
\text { type II NKT }\end{array}$} & \multirow[t]{3}{*}{ IFN- $\gamma$} & $\begin{array}{l}\text { CD1d-dependent (ligand } \\
\text { yet to be defined) }\end{array}$ & $\begin{array}{l}\text { Immunoregulatory functions that } \\
\text { prevent secretion of pro-inflammatory } \\
\text { cytokines and recruitment of } \\
\text { inflammatory cells }\end{array}$ & $\begin{array}{l}\text { Enhanced mortality and weight } \\
\text { loss in } J_{\alpha} 18^{-/-} \text {and } V_{\alpha} 14 \mathrm{i} \mathrm{Tg} \text { mice }\end{array}$ & $(108)$ \\
\hline & & & \multirow{2}{*}{$\begin{array}{l}\text { Indirectly evidenced } \\
\text { analyzing Nur77 } \\
\text { expression }\end{array}$} & - & - & \\
\hline & & & & $\begin{array}{l}\text { Opposite functions for type I and } \\
\text { type II NKT cells to be considered }\end{array}$ & Protection in $C D 1 d^{-/-}$mice & \\
\hline & \multirow[t]{4}{*}{ MAIT } & $\mathrm{IFN}-\gamma$ & \multirow{4}{*}{$\begin{array}{l}\text { MR1- and cytokine- } \\
\text { mediated (IL-12 and IL-18) } \\
\text { Only demonstrated in vitro }\end{array}$} & \multirow{4}{*}{$\begin{array}{l}\text { Recruitment of adaptive } \mathrm{CD}^{+} \text {and } \\
\mathrm{CD} 8^{+} \mathrm{T} \text { cells through reprogramming } \\
\text { of monocytes int moDC }\end{array}$} & \multirow{4}{*}{$\begin{array}{l}\text { Higher bacterial burden } \\
\text { in } \mathrm{Mr1}^{-/-} \text {mice }\end{array}$} & \multirow[t]{4}{*}{$(109,110)$} \\
\hline & & $\mathrm{TNF}-\alpha$ & & & & \\
\hline & & $\mathrm{IL}-17$ & & & & \\
\hline & & GM-CSF & & & & \\
\hline \multirow[t]{6}{*}{$\begin{array}{l}\text { Streptoccocus } \\
\text { pneumoniae } \\
\text { (serotype } 1 \text { and 3) }\end{array}$} & \multirow[t]{3}{*}{ Type I NKT } & IFN- $\gamma$ & $\begin{array}{l}\text { Dependent on the strain used: } \\
\text { Serotype 3: CD1d-mediated } \\
\text { ( } \alpha \text {-glucosyldiacylglycerol from } \\
\text { the pathogen) and cytokine- } \\
\text { mediated (IL-12) }\end{array}$ & Neutrophilia & $\begin{array}{l}\text { Enhanced mortality, weight loss } \\
\text { and bacterial loads in } J \alpha 18^{-/-} \\
\text {mice compared to WT controls }\end{array}$ & $\begin{array}{c}(92 \\
111-115)\end{array}$ \\
\hline & & IL-17A & Serotype 1: cytokine- & - & & \\
\hline & & & mediated: IL-12 for IFN- $\gamma$ & Bacterial clearance & & \\
\hline & \multirow[t]{3}{*}{ MAIT } & IFN- $\gamma$ & MR1-dependent & $\begin{array}{l}\text { Cytotoxic activity in vitro on Sp- } \\
\text { infected airway epithelial cells }\end{array}$ & To be tested & $(116)$ \\
\hline & & IL-17A & Only tested in vitro & - & & \\
\hline & & & & $\begin{array}{l}\text { Killing efficacy is isolate specific } \\
\text { and dependent on riboflavin } \\
\text { biosynthesis pathway activity }\end{array}$ & & \\
\hline \multirow{10}{*}{$\begin{array}{l}\text { Infuenza A virus } \\
(H 1 N 1, H 3 N 2 \text {, } \\
\text { and H3N1) }\end{array}$} & \multirow[t]{8}{*}{$\begin{array}{l}\text { Type I (and } \\
\text { II) NKT }\end{array}$} & IFN- $\gamma$ & $\begin{array}{l}\text { H1N1 (IFN- } \gamma): \\
\text { CD1d-dependent }\end{array}$ & \multirow{8}{*}{$\begin{array}{l}\text { Pro-inflammatory functions: } \\
\text { promote Influenza A virus } \\
\text { (IAV)-specific CD8+ T cell response by: } \\
\text { (1) inhibition of MDSC functions } \\
\text { (2) Regulation of DC migration to } \\
\text { the lung-draining lymph nodes } \\
\text { Regulatory functions: } \\
\text { (1) Control of inflammatory } \\
\text { monocyte recruitment } \\
\text { (2) Control of IFN- } \gamma \text { production } \\
\text { by NK cells }\end{array}$} & $\begin{array}{l}\text { Increased mortality and weight } \\
\text { loss in } J \alpha 18^{-/-} \text {and } C d 1 d^{-/-} \text {mice }\end{array}$ & \multirow[t]{8}{*}{$(117-120)$} \\
\hline & & IL-4/IL-13 & - & & - & \\
\hline & & IL-22 & H3N2 (IL-22): CD1d- & & Enhanced tissue damages & \\
\hline & & & $\begin{array}{l}\text { independent and cytokine- } \\
\text { mediated: IL-1 } \beta \text { and IL-23 }\end{array}$ & & in $J_{\alpha} 18^{-/-}$mice & \\
\hline & & & through engagement of & & & \\
\hline & & & TLRs and RNA helicases & & & \\
\hline & & & - & & $\begin{array}{l}\text { Delayed viral clearance in } J \alpha 18^{-/-} \\
\text {and } C d 1 d^{-/-} \text {mice }(H 1 N 1)\end{array}$ & \\
\hline & & & $\begin{array}{l}\text { H3N1 (IL-4/IL-13): } \\
\text { TLR7-dependent }\end{array}$ & & $\begin{array}{l}\text { No changes observed } \\
\text { in } J_{\alpha} 18^{-/-} \text {mice }(\mathrm{H} 3 \mathrm{~N} 2)\end{array}$ & \\
\hline & \multirow{2}{*}{$\begin{array}{l}\text { MAIT (only } \\
\text { tested with } \\
\text { human } \\
\text { MAIT cells) }\end{array}$} & IFN- $\gamma$ & MR1-independent & \multirow{2}{*}{$\begin{array}{l}\text { Cytotoxic activity on } \\
\text { IAV-infected cells }\end{array}$} & \multirow[t]{2}{*}{ To be done } & \multirow[t]{2}{*}{$(68,75)$} \\
\hline & & TNF- $\alpha$ & $\begin{array}{l}\text { Cytokine-driven: IL-12, } \\
\text { IL-18, and type I IFNs }\end{array}$ & & & \\
\hline
\end{tabular}


in the lung tissue and pleural effusions of TB patients (71) suggesting a recruitment to the inflamed tissue. In addition, one can argue that this relative disappearance can also rely on other mechanisms such as increased apoptosis (147) or TCR downmodulation (rendering them virtually undetectable) as a consequence of overactivation. Indeed, MAIT cells from blood and pleural effusions of TB patients displayed a phenotype of activated/memory cells $\left(\mathrm{CD} 69^{+} \mathrm{CD} 45 \mathrm{RO}^{+}\right)$associated with a higher capacity to produce antimycobacterial cytokines such as IFN- $\gamma$ and TNF- $\alpha$ (147). This phenotype can be further exemplified since MAIT cells from these patients had a reduced response to unspecific restimulation (147). Reminiscent with the data generated in studies on NKT cells, MAIT cells from TB patients expressed high levels of PD-1 and ex vivo PD-1 blockade restored IFN- $\gamma$ production by these latter (147). Human MAIT cells can also mediate cytotoxicity against mycobacteria-infected cells. Thus, they can recognize and kill M. tuberculosis-infected cells including DCs and lung epithelial cells in a MR1-dependent manner $(71,148,149)$. Of note, nonMAIT V $\alpha 7.2-J \alpha 12$ MR1-restricted T cells can also efficiently kill BCG-infected THP-1 (a monocytic cell line) (72).

\section{Other Bacteria}

Concurrent literature for NKT cells and MAIT cells in the context of bacterial lung infection is rather limited. Some data are nevertheless available for models of pneumonia induced by the Gram-negative bacterium Francisella tularensis or by the Grampositive bacterium Streptococcus pneumoniae.

\section{Francisella tularensis}

Francisella tularensis is the causative agent of tularemia (also referred to as rabbit fever); a zoonosis that spreads via arthropod vectors after contact with infected animals (150). Depending on the site of infection, tularemia can lead to several clinical manifestations including pneumonia, the most deadly form of the disease with a mortality rate up to $60 \%$ (151). Incidence rates have drastically dropped over the last century despite some local outbreaks have been noticed over the last decades (152). In addition, $F$. tularensis can be considered as a potential agent for bioterrorism (153). Given the high virulence of $F$. tularensis, preclinical data mainly derived from attenuated strains such as $F$. tularensis Live Vaccine Strain (LVS).

\section{NKT Cells}

Surprisingly, the role of NKT cells has only recently emerged in experimental pulmonary tularemia (108), a model of immunopathology that can be related to sepsis-like disorder (154). To explore this, authors studied survival and body weight loss in various mouse strains including $J \propto 18^{-/-}, C d 1 d^{-1-}$, and $V \alpha 14 i$ $\mathrm{Tg}$ mice. Unfortunately, due to the apparent variability in this model and the lack of data using all mouse lines in a single experiment, interpretation of the results is not straightforward (108). Thus, $J \alpha 18^{-/-}$and $V \alpha 14 i \mathrm{Tg}$ mice were more susceptible to infection compared to WT controls while $C d 1 d^{-/-}$mice were more resistant. Altogether, these data implied that NKT cells probably play deleterious role during pulmonary tularemia even if data obtained with $J \alpha 18^{-/-}$mice do not support this hypothesis.
To explain this, authors claimed that CD1d-deficient mice represent a better model than $J \alpha 18^{-/-}$mice to study the role of NKT cells in disease (108). However, several additional hypotheses are worth mentioning to explain these results. First, it is possible that type I NKT and type II NKT cells play opposite functions during pulmonary tularemia. Although, Vo14i Tg mice present a similar phenotype than $J \alpha 18^{-/-}$mice, it has to be kept in mind that type I NKT cells generated from $V \alpha 14 i \mathrm{Tg}$ mice present unique characteristics compared to bona fide type I NKT cells and a profound bias in their $\mathrm{CD}^{+} \mathrm{T}$ cell repertoire (155). Given the role of MAIT cells during pulmonary tularemia (see below), the phenotype observed in $C d 1 d^{-/-}$mice can also at least partially rely on the high level of MAIT cells in these mice (39). Conversely, $J \alpha 18^{-/-}$mice are likely to have reduced MAIT cell frequencies since $60 \%$ of the TCR $\alpha$ repertoire diversity is actually lacking in these mice (40).

The resistance of $C d 1 d^{-1-}$ mice to tularemia is mainly associated with enhanced formation of tertiary lymphoid structures in lungs of infected mice associated with mitigated inflammation including reduced pro-inflammatory cytokines and inflammatory cell recruitment (108). Collectively, NKT cells have deleterious functions during tularemia although a more refine analysis of the potential differential roles of type I NKT and type II NKT cells in this model should be considered.

\section{MAIT Cells}

$\mathrm{CD}^{-}{ }^{-} \mathrm{CD} 8^{-}$double-negative (DN) $\mathrm{T}$ cells have been shown to represent a major responding $\mathrm{T}$ cell subset in the lungs of LVSinfected mice (156). Despite the lack of specific tools, authors unequivocally demonstrated a couple of years later that this strong accumulation of DN T cells during pulmonary LVS infection was mainly attributable to MAIT cells (109). Indeed, most of these cells expressed transcripts for the invariant V $\alpha 19$-J $\alpha 33 \alpha$-chain rearrangement associated with TCR $\beta$-chains containing V $\beta 6$ or $\mathrm{V} \beta 8$ segments (109). In addition, the accumulation of DN T cells was absent in $\mathrm{Mrl}^{-/-}$mice. Interestingly, $\mathrm{MrI}^{-/-}$mice exhibited higher bacterial burden in the lungs compared to WT mice from day 10 postinfection (109).

During in vivo infection, MAIT cells produced antibacterial cytokines including IFN- $\gamma$, TNF- $\alpha$, GM-CSF, and IL-17A and contributed to recruitment of adaptive $\mathrm{CD} 4^{+}$and $\mathrm{CD} 8^{+} \mathrm{T}$ cells $(109,110)$. Interestingly, MAIT cells controlled the recruitment of activated $\mathrm{CD}^{+}{ }^{+} \mathrm{T}$ cells through GM-CSF-mediated reprogramming of monocytes into monocyte-derived DCs (110).

In addition, cultures of MAIT cells with LVS-infected monocytes led to a MAIT cell-dependent reduction in bacterial growth, a mechanism that relied on secretion of IFN- $\gamma$, TNF- $\alpha$, and nitric oxide (109). In vitro activation of MAIT cells in this model was dependent on MR1 and the activating cytokines IL-12 and IL-18 according to the strain of bacterium used $(109,157)$. Altogether, MAIT cells appear as important antibacterial players during tularemia.

\section{Streptococcus pneumoniae}

Streptococcus pneumoniae (the pneumococcus) is the major bacterium responsible for community-acquired pneumonia in western countries and accounts for $\sim 2$ million of deaths per 
year worldwide. In normal conditions, S. pneumoniae colonizes asymptomatically nasopharynx of healthy individuals. However, when the immune equilibrium is broken, pneumococcus carriage can lead to mild disease such as otitis media or sinusitis and more occasionally turns into severe complications such as pneumonia, sepsis, and meningitis (158). In addition, presence of S. pneumoniae is often found in biological fluids of hospitalized patients for severe influenza A infection (159) as well as patients with exacerbated chronic lung inflammation such as chronic obstructive pulmonary disease (160).

Despite vaccination is an efficient strategy to prevent pneumococcus spread and to control infections, the available vaccines have, however, some issues [for reviews, see Ref. (161, 162)]. In addition, the emergence of antibiotic-resistant strains (163) represents an important threat for the management of pneumococcal infections in clinics.

\section{NKT Cells}

Many studies have highlighted an important role for type I NKT cells in host response against pulmonary pneumococcal infection. Using S. pneumoniae serotype 1 or 3 strains, we and others reported that $J \alpha 18^{-/-}$mice were more susceptible to infection and displayed higher bacterial burden compared to WT controls (111-113). The underlying mechanisms of this protective activity rely on IFN- $\gamma$ secretion by type I NKT cells that regulate early recruitment of neutrophils (113). Elaborately, type I NKT cell-derived IFN- $\gamma$ controls the secretion of CXCL2 and TNF- $\alpha$ (113), two critical mediators of lung neutrophilia. Type I NKT cells migrate to the lung parenchyma only $24 \mathrm{~h}$ after $S$. pneumoniae infection in a CCL17-dependent manner, a mechanism, which is crucial for mouse survival (92). The mechanisms involved in type I NKT cell activation during $S$. pneumoniae infection have been extensively explored and depends on activating cytokines, pneumococcal-derived Ag, or both according to the strain studied. First, akin to other bacteria, the cell wall of several $S$. pneumoniae strains is constituted of glycolipids ( $\alpha$-glucosyldiacylglycerol) that can serve as CD1drestricted type I NKT cell Ags (114). The recognition of this Ag in vivo is important for host response to S. pneumoniae (114). The general mechanism that allows accessibility and loading of such microbial-derived Ags into CD1d are currently unknown and deserve further investigations. In addition, type I NKT cell activation during pneumococcal infection is also dependent on the release of IL-12 especially by $\mathrm{CD}_{103^{+}} \mathrm{DCs}(112,115)$. No data are currently available regarding type II NKT cells during pneumococcal infection.

Exogenous activation of type I NKT cells protects against lethal S. pneumoniae infection independently of the strain used $(113,164)$. Mechanistically, this protective activity relied on IFN- $\gamma$ and IL-17A production and subsequent neutrophil recruitment that controlled bacterial elimination (164). While these protective effects have been obtained using $\alpha$-GalCer, exogenous activation of type I NKT cells with $\alpha$-mannosylglycolipids has also been shown to partially protect mice against pneumococcal infection (165).

Surprisingly, despite strong evidence for a critical role in host response to pneumococcus in experimental models, no clinical studies have so far addressed the dynamics and functions of NKT cells in patients with severe $S$. pneumoniae-driven pneumonia.

Type I NKT cells have been shown to provide help for $\mathrm{B}$ cells in mounting $\mathrm{Ab}$ responses $(26,166)$. In line with this literature, NKT cells have important role in the production of specific antipneumococcal Abs and class switching in response to pneumococcal vaccines in experimental models $(167,168)$. A recent clinical study enrolling vaccinated subjects with the 23-valent pneumococcal polysaccharide vaccine reported a positive correlation between frequency of circulating type I NKT cells and the serum concentrations of specific IgG directed against serotypes 14 and 19F (167). Interestingly, injection of liposomes containing synthetic NKT cell Ags and pneumococcal capsular polysaccharides led to the generation of long-term memory B cell response $(169,170)$. Generation of such a response was dependent on the recognition of lipids and capsular polysaccharide antigens by type I NKT cells and $\mathrm{B}$ cells, respectively, to elicit cognate and direct NKT-B cell interactions. Thus, harnessing NKT cell functions (adjuvant effect or B cell help) during pneumococcal vaccination might represent an interesting avenue of research in the future.

Of note, pneumococcal infection and vaccination have been proposed to reduce airways allergic diseases as a result of immune modulation in both experimental and clinical studies (171-173). Interestingly, this mechanism relied on the regulatory functions of some components of the pneumococcus including the bacterial toxin pneumolysin and type-3-polysaccharide (174). These molecules induced the generation of regulatory T cells that control type I NKT cell accumulation and limit the development of airway hyperresponsiveness (174).

\section{MAIT Cells}

Early works suggested that MAIT cells do not react to Streptococcus group A (69). However, genomic and transcriptomic analyses of numerous strains indicate that $S$. pneumoniae expresses enzymes involved in the synthesis of riboflavin metabolites $(175,176)$ as well as a highly conserved riboflavin operon (177). Thus, activation and functions of MAIT cells during pneumococcal infection have recently been investigated. Human MAIT cells can produce IFN- $\gamma$ in response to accessory cells infected by S. pneumoniae clinical isolates $(116,177)$. Interestingly, the magnitude of MAIT cell response differed from one isolate to another and was proposed to depend on genetic variations in their expression of the riboflavin pathway (116) suggesting a role for MR1-dependent Ags in this model. Conversely, another study suggested that MAIT cell activation, in response to THP-1 cells cultured with fixed pneumococci was unchanged upon MR1 blockade but was fully abrogated following IL-12 and IL-18 neutralization (177). This discrepancy might stem from differences in experimental design as well as in the level of metabolic activity (riboflavin metabolism) of the various strain used. In line with the first hypothesis, the use of macrophages in the culture assay led to IFN- $\gamma$ release by MAIT cells in a MR1-dependent manner (177). Environmental factors can also determine the generation of MAIT cell Ags by the pneumococci. Thus, modulation in riboflavin availability in the culture assay 
significantly influenced MAIT cell activation in response to pneumococcus-infected DCs. Specifically, excess of riboflavin blunted MAIT cell response while culture in riboflavin-free assay medium increased MAIT cell activity $(116,177)$. In addition, heat stress can induce the riboflavin operon in S. pneumoniae resulting in higher MAIT cell Ag availability (177).

Using in vivo models of pneumococcal infections with virulent or avirulent strains in $\mathrm{V} \alpha 19 \mathrm{i} \mathrm{Tg} \times \mathrm{C}^{-l-}$ mice, a small proportion of lung MAIT cells produced IFN- $\gamma$ and IL-17A (116). Although a more detailed kinetic analysis is required, these levels were relatively low compared to cytokine production observed for other unconventional $\mathrm{T}$ cell subsets in this model including $\gamma \delta \mathrm{T}$ cells and NKT cells $(112,178,179)$. However, the precise functions of MAIT cells in pneumococcus-induced pneumonia are currently unknown since data from either $\mathrm{MrI}^{-1-}$ or $\mathrm{V} \alpha 19 \mathrm{iTgC} \alpha^{-/-} \mathrm{Mr}^{-/-}$mice are not yet available.

Akin to NKT cells, the phenotype and dynamics of MAIT cells in patients with severe pneumonia associated with presence of pneumococci are rather limited. Of note, the levels of circulating MAIT cells in critically ill patients with severe bacterial infections were markedly decreased compared to age-matched healthy donors (180). Surprisingly, the decrease in MAIT cell frequency was less pronounced in patients with streptococcal infections including pneumonia compared to non-streptococcal infections (180). This might imply a minimal role for MAIT cells during S. pneumoniae-induced pneumonia in humans although this observation should be confirmed by the use of MR1 tetramers.

\section{Influenza A Virus (IAV)}

Influenza A viruses belong to the family of Orthomyxoviridae viruses and are characterized by a segmented single-stranded RNA genome of negative polarity. IAV can be further segregated regarding the expression of two important proteins namely hemagglutinin and neuraminidase proteins. IAV are responsible for seasonal highly contagious infections characterized by a severe pulmonary immune pathology leading to human morbidity and mortality (181). About five millions of clinical cases and 250,000 to 500,000 deaths are reported worldwide every year $(182,183)$. More sporadically, transversal infections of animal strains to humans or co-infection with multiple IAV strains in individuals can result in re-assortment of genes generating highly virulent new strains leading to life-threatening pandemics $(184,185)$. Recent epidemiological studies also indicated that hospitalized patients for severe pneumonia during IAV epidemics or pandemics are often coinfected with bacteria including S. pneumoniae (methicillinresistant) Staphylococcus aureus, Pseudomonas aeruginosa, and Haemophilus influenza (186). These secondary bacterial infections contribute significantly to the excess morbidity and mortality of influenza [for a review, see Ref. (186)]. Mechanistically, infection with IAV dampens innate antibacterial immunity and alters pulmonary barrier functions thus favoring local bacterial outgrowth and dissemination from the lungs [for reviews, see Ref. $(187,188)$ ]. Considering the clinical impact of bacterial superinfection post-influenza, the development of preclinical models should be encouraged for proper translational studies.

\section{NKT Cells}

We and others have demonstrated the pivotal role of type I NKT cells in host response to IAV infection. Keeping in mind that they represent a heterogeneous population composed of subsets endowed with specialized functions, type I NKT cells have been shown to exert multiple functions during the course of IAV infection. Despite mechanisms differ from one experimental setting to another, type I NKT cell deficiency has been consensually shown to increase susceptibility (survival, enhanced inflammation) in several experimental influenza $(\mathrm{H} 1 \mathrm{~N} 1, \mathrm{H} 3 \mathrm{~N} 1$, and H3N2) infection models (117-119). For instance, a pioneer study described a new mechanism in which type I NKT cells could inhibit the suppressive functions of myeloid-derived suppressor cells resulting in enhanced IAV-specific $\mathrm{CD}^{+} \mathrm{T}$ cell response, enhanced viral clearance, and increased survival (119). We also described a role for type I NKT cells in mounting IAV-specific $\mathrm{CD}^{+} \mathrm{T}$ cell response (118). In our model, this effect relied on NKT cell-mediated control of lung $\mathrm{CD}_{103}{ }^{+} \mathrm{DC}$ emigration to the draining lymph nodes (118). In parallel, type I NKT cells exert anti-inflammatory functions during IAV infection, thus preventing immunopathogenesis. First, type I NKT cells control the recruitment of inflammatory monocytes (117) as well as the production of IFN- $\gamma$ by NK cells (118), two mechanisms that can blunt IAV-associated pathogenesis $(189,190)$. In addition, type I NKT cells produced the tissue protective cytokine IL-22 during the early course of IAV infection (120). Although it did not affect viral loads in vivo (191), IL-22 protected against epithelial damages due to viral replication $(120,192)$. Through this mechanism, IL-22 might reduce secondary bacterial infection post-influenza $(191,193)$.

The activation mechanisms of type I NKT cells during IAV infection have been proposed to rely on either CD1d-dependent or CD1d-independent pathways. First, type I NKT cells have been shown to directly control the suppressive activities of myeloid-derived suppressor cells in a CD1d-dependent manner (119). The nature of the ligand involved is yet to be defined but appears to be a neo-synthesized GSL of host origin (119). On the other hand, we demonstrated that IL-22 production by type I NKT cells during IAV infection was dependent on IL- $1 \beta$ and IL-23 secretion by accessory cells and did not require CD1d (120).

The potential role of type II NKT cells during IAV is currently unknown. Of note, $C D 1 d^{-1-}$ mice are more susceptible to H1N1 IAV infection than $J \alpha 18^{-/-}$mice although no differences between genotypes were observed regarding viral loads (119). This might suggest a role for type II NKT cells in regulating host immune response rather than controlling viral replication.

The role of type I NKT cells in secondary bacterial infection post-influenza has also been examined. Using a model of post-IAV invasive secondary pneumococcal infection, type I NKT cells were shown to limit susceptibility to superinfection and lethal viral/bacterial synergism (112). In this setting, type I NKT cells act early after IAV infection by preventing tissue damages (through IL-22) (118). On the other hand, at the peak of bacterial susceptibility, type I NKT cells are in a state of hyporesponsiveness; an effect that depends on the immunosuppressive cytokine IL-10 (112). Interestingly, IL-10 blockade restored type 
I NKT cell activity and slightly increased resistance to bacterial superinfection (112). Of interest, $\alpha$-GalCer instillation tempered secondary bacterial infection with lower bacterial outgrowth and dissemination (194) suggesting that type I NKT cells could be instrumental in clinics to combat IAV infection and its complications.

\section{MAIT Cells}

Since they cannot generate MAIT cell Ags derived from the riboflavin pathway, viruses were intuitively thought to be unable to activate MAIT cells. Nevertheless, MAIT cells can be activated in the absence of TCR ligation by many cytokines (e.g., IL-1 $\beta$, IL-2, IL-7, IL-12, IL-15, IL-18, IL-23, and type I IFN) $(75,195,196)$ released by accessory cells through engagement of various pattern recognition receptors including toll-like receptors and/or nodlike receptors.

Pioneer experiments demonstrated that MAIT cells isolated from V $\alpha 19$ iTg mice do not respond to DCs infected with a broad set of viruses (69). However, as previously mentioned, MAIT cells from $\mathrm{Tg}$ mice differ from conventional ones in that they present a naive profile and are devoid of the key transcription factor PLZF (67). Since PLZF controls expression of many chemokine/cytokine receptors (197) including IL-7R $\alpha$ and IL-18R $\alpha$ on MAIT cells (39), this can simply explain the absence of response of MAIT cells from $\mathrm{Tg}$ mice to virus-induced activating cytokines. The putative functions of MAIT cells during experimental influenza infection are still ignored.

Human MAIT cells can respond in vitro to IAV by CD69 and granzyme B upregulation as well as IFN- $\gamma$ secretion $(68,75)$. In these settings, purified or enriched MAIT cells were cultured with peripheral blood mononuclear cells and IAV-infected epithelial cells or IAV-exposed macrophages. Mechanistically, MAIT cell activation was dependent on IL-18 secretion by monocyte/macrophages and did not require functional MR1 molecule $(68,75)$. Notably, IAV replication was not required since ultraviolet-irradiated IAV were still able to activate MAIT cells (75). These data suggest a potential role for MAIT cells in host response during IAV infection.

Compared to healthy donors, the frequency of circulating MAIT cells was decreased in a small cohort of 16 patients hospitalized for severe pneumonia due to infection with the Asian lineage avian IAV (H7N9) (68). Interestingly, individuals who recovered from pneumonia had higher levels of circulating MAIT cells compared with those who succumbed (68). Another clinical study confirmed the reduced MAIT cell frequencies in patients with acute IAV infection (75). This decrease was even more pronounced in critically ill patients admitted in intensive care unit compared to patients with mild symptoms (75).

\section{Future Directions}

Natural killer T cells and MAIT cells participate in host response to numerous respiratory pathogens. These cells might have some overlapping functions during lung infections. To better elucidate their differential contribution, integrated analysis of activation dynamics and functions of NKT cells and MAIT cells in experimental models as well as in patients with severe lung infection should be encouraged. In addition to the models discussed above, NKT cells have been reported to play important role in vivo in many other areas of lung infections including respiratory syncytial virus, $P$. aeruginosa, Legionella pneumophilia, Chlamydia spp. as well as the fungi Cryptococcus neoformans and Aspergillus fumigates [for a review, see Ref. (198)]. Thus, it would be worth to examine the activation status and putative functions of MAIT cells in these models.

Regarding the limitations enumerated previously, the conclusions drawn from the phenotype observed in $J \alpha 18^{-/-}, C d 1 d^{-1-}$, $M r 1^{-/-}, V \alpha 14 i \mathrm{Tg}$, and $V \alpha 19 i \mathrm{Tg}$ mice should be taken with caution. Therefore, reconstitution experiments with organ-specific cells in these knock-out/transgenic mice appear mandatory to confirm previous findings. In addition, selective in vivo depletion of these populations by means of monoclonal $\mathrm{Ab}$ represents an alternative approach as recently reported for type I NKT cells (199). Additionally, since these cells are likely to regulate homeostasis and functions of each other, crossing NKT cell- and MAIT cell-deficient mice will certainly provide new interesting tools to determine the specific or redundant functions of these cells.

Although the evolutionary conservation of CD1d and MR1 across mammals renders rodent models of pulmonary infections relevant to study NKT cell and MAIT cell biology, the expected widespread of humanized mouse models will surely provide new insights on the development and regulation of the immune response during lung infections. In addition, these models will be likely to highlight the NKT cell and MAIT cell species' differences in data generated from mouse and human studies.

The current therapeutical arsenal for clinicians to combat lung infections is almost exclusively based on the use of antimicrobial drugs and standardized daily management. However, fatal outcomes in patients with severe lung infection are often associated with dysregulated immune response. In this condition, innovative strategies of immune intervention targeting host factors should be proposed. Thus, according to their immunoregulatory functions, NKT cells and MAIT cells are well poised for cell-based therapy to fight lung infections and their complications.

\section{THERAPEUTIC OPPORTUNITIES AND CONCLUDING REMARKS}

The last century has witnessed incredible progresses in the control of infectious diseases, which significantly reduced the human death toll, especially in western countries. However, the incidence of lung infections has significantly increased over the last decades due to major changes in environment and lifestyle (leading to immune homeostasis dysregulation and increased contact with new pathogens). These events represent key societal and public health threats. In addition, booming in resistance to antimicrobial drugs also constitute a new challenge for clinicians. Thus, the development of new therapeutical options to combat lung infections and their complications is urgently needed.

Harnessing the biology of CD1- and MR1-restricted cells is currently highly regarded to fight cancer $(200,201)$. By contrast, exploiting NKT cell and MAIT cell in clinical trials for lung infections is still in its infancy. Yet, targeting these cells offers several advantages that may lead to improve current management of 
lung infections. First, NKT cells and MAIT cells are restricted by quasi-monomorphic Ag-presenting molecules. Thus, they have the potential to be manipulated by "universal" ligands rendering most of patients eligible for NKT/MAIT cell-based therapies. Second, engineering of polarizing Ags (only developed for NKT cells so far) allows considering the generation of tailored-made responses according to the immune profile of the patients. Last, experimental and clinical studies indicated that NKT cell-based therapies are safe and feasible (202). Thus, many strategies might be tested to harness CD1d- and MR1-restricted T cell functions during lung infections.

The adjuvant properties of NKT cells and MAIT cells could be exploited in the design of more efficient vaccines. The replacement of conventional adjuvants by NKT/MAIT cell Ags ( $\alpha$-GalCer and its analogs, ribloflavin metabolites) in classical vaccines could be used to optimize the magnitude and duration of the adaptive immune. Through the ability of NKT cells and MAIT cells to subsequently activate/mature accessory cells including DCs, this strategy is likely to improve the development of the memory response.

In addition, these Ags might also generate short-term and organ-specific immune responses with positive outcomes (8). As clinical studies predominantly reported decreased levels of circulating NKT cells and MAIT cells in patients with severe pneumonia and associated with reduced prognosis, the proliferative activity (in vivo or ex vivo) of these Ags might help to the replenishment of the NKT/MAIT cell pool. Of note, the highly unstable nature of MAIT cell Ags precludes its use in expansion protocols and, therefore, represents a major limitation in these strategies. However, recent efforts in generating more stable forms of MAIT cell Ags $(203,204)$ should help to circumvent this issue in the near future. Despite being more laborious, the expansion of MAIT cells can also be achieved through reprogramming to pluripotent stem cells and subsequent redifferentiation using the stromal cell line OP9/DL1 (205).

The effects of combining NKT/MAIT cell Ags with antimicrobial drugs should also be encouraged. By reducing the concentrations of antibiotics or antiviral drugs used in conventional therapy for a similar antimicrobial activity, this strategy could help to lessen the development of drug resistance.

Chimeric Ag receptor (CAR) T cell therapy using conventional $\mathrm{T}$ cells has recently emerged as a promising approach in clinics (206). However, the high polymorphism in HLA system limits the development of CAR T cell therapy due to potential appearance of side effects such as graft-versus-host disease. Since many bacteria express glycolipid Ags for NKT cells, the recent

\section{REFERENCES}

1. Bendelac A, Lantz O, Quimby ME, Yewdell JW, Bennink JR, Brutkiewicz RR. CD1 recognition by mouse NK1+ T lymphocytes. Science (1995) 268:863-5. doi: $10.1126 /$ science.7538697

2. Lantz $\mathrm{O}$, Bendelac A. An invariant $\mathrm{T}$ cell receptor alpha chain is used by a unique subset of major histocompatibility complex class I-specific CD4+ and CD4-8- T cells in mice and humans. J Exp Med (1994) 180:1097-106. doi:10.1084/jem.180.3.1097

3. Michel M-L, Keller AC, Paget C, Fujio M, Trottein F, Savage PB, et al. Identification of an IL-17-producing NK1.1(neg) iNKT cell population generation of CAR-expressing NKT cells $(207,208)$ offers an interesting and highly innovative approach in the context of antibacterial therapies. Similar approaches could be developed in the future with CAR-expressing MAIT cells.

Dealing with their hyporesponsiveness during lung infections represents another food for thought for NKT/MAIT cell-based therapy. Increased expression of the checkpoint inhibitor PD-1 on NKT cells and MAIT cells in patients with TB has been associated with reduced capacity to produce antimycobacterial cytokines (136, 137, 147). Blockade of PD-1 expression has recently emerged as a potential strategy for infectious diseases including lung infection and sepsis (209-212). Thus, the possibility that the protective activity of anti-PD-1 treatments might partially rely on the restoration of NKT cell and MAIT cell functions should be considered. Treatment with $\alpha$-GalCer has also been shown to lead to NKT cell hyporesponsiveness due to TCR internalization (213) and/or induction of PD-1 expression (214). New formulations and a better delivery of $\alpha$-GalCer to potent Ag-presenting cells (such as DCs) by means of dedicated nanovectors can prevent the development of NKT cell anergy (215-218). These strategies might optimize NKT cell-based therapies to combat respiratory infections.

Natural killer T cells and MAIT cells have become the focus of intense investigation in the last decade. It is now clear that harnessing the biology of these cells has the potential to offer innovative therapeutic approaches in a medical field in which clinicians require a new and efficient arsenal to treat infections and their complications.

\section{AUTHOR CONTRIBUTIONS}

All authors listed have made a substantial, direct, and intellectual contribution to the work and approved it for publication.

\section{ACKNOWLEDGMENTS}

We apologize to colleagues whose works could not be cited due to space constraints. CP is supported by the INSERM and FT by the CNRS.

\section{FUNDING}

This work was supported by the Inserm, the CNRS, the University of Lille Nord de France, the Pasteur Institute of Lille, and the Institut National du Cancer (INCa, under reference R08046EE/ RPT08003EEA and R13071EE/RPT13001EEA). involved in airway neutrophilia. J Exp Med (2007) 204:995-1001. doi:10.1084/ jem.20061551

4. Coquet JM, Chakravarti S, Kyparissoudis K, McNab FW, Pitt LA, McKenzie BS, et al. Diverse cytokine production by NKT cell subsets and identification of an IL-17-producing CD4-NK1.1- NKT cell population. Proc Natl Acad Sci U S A (2008) 105:11287-92. doi:10.1073/pnas.0801631105

5. Godfrey DI, Stankovic S, Baxter AG. Raising the NKT cell family. Nat Immunol (2010) 11:197-206. doi:10.1038/ni.1841

6. Rossjohn J, Pellicci DG, Patel O, Gapin L, Godfrey DI. Recognition of CD1d-restricted antigens by natural killer T cells. Nat Rev Immunol (2012) 12:845-57. doi:10.1038/nri3328 
7. Bendelac A, Savage PB, Teyton L. The biology of NKT cells. Annu Rev Immunol (2007) 25:297-336. doi:10.1146/annurev.immunol.25.022106.141711

8. Godfrey DI, Uldrich AP, McCluskey J, Rossjohn J, Moody DB. The burgeoning family of unconventional T cells. Nat Immunol (2015) 16:1114-23. doi:10.1038/ni.3298

9. Kawano T, Cui J, Koezuka Y, Toura I, Kaneko Y, Motoki K, et al. CD1drestricted and TCR-mediated activation of valpha14 NKT cells by glycosylceramides. Science (1997) 278:1626-9. doi:10.1126/science.278.5343.1626

10. Zajonc DM, Girardi E. Recognition of microbial glycolipids by natural killer T cells. Front Immunol (2015) 6:400. doi:10.3389/fimmu.2015.00400

11. Van Kaer L, Parekh VV, Wu L. The response of CD1d-restricted invariant NKT cells to microbial pathogens and their products. Front Immunol (2015) 6:226. doi:10.3389/fimmu.2015.00226

12. Tupin E, Kinjo Y, Kronenberg M. The unique role of natural killer $\mathrm{T}$ cells in the response to microorganisms. Nat Rev Microbiol (2007) 5:405-17. doi:10.1038/ nrmicrol657

13. Doisne J-M, Soulard V, Bécourt C, Amniai L, Henrot P, Havenar-Daughton C, et al. Cutting edge: crucial role of IL-1 and IL-23 in the innate IL-17 response of peripheral lymph node NK1.1- invariant NKT cells to bacteria. J Immunol (2011) 186:662-6. doi:10.4049/jimmunol.1002725

14. Paget C, Mallevaey T, Speak AO, Torres D, Fontaine J, Sheehan KCF, et al. Activation of invariant NKT cells by toll-like receptor 9-stimulated dendritic cells requires type I interferon and charged glycosphingolipids. Immunity (2007) 27:597-609. doi:10.1016/j.immuni.2007.08.017

15. Tyznik AJ, Verma S, Wang Q, Kronenberg M, Benedict CA. Distinct requirements for activation of NKT and NK cells during viral infection. J Immunol (2014) 192:3676-85. doi:10.4049/jimmunol.1300837

16. Lynch L, O'Shea D, Winter DC, Geoghegan J, Doherty DG, O'Farrelly C. Invariant NKT cells and $\mathrm{CDld}(+)$ cells amass in human omentum and are depleted in patients with cancer and obesity. Eur J Immunol (2009) 39:1893-901. doi:10.1002/eji.200939349

17. Lee YJ, Holzapfel KL, Zhu J, Jameson SC, Hogquist KA. Steady-state production of IL- 4 modulates immunity in mouse strains and is determined by lineage diversity of iNKT cells. Nat Immunol (2013) 14:1146-54. doi:10.1038/ ni.2731

18. Engel I, Seumois G, Chavez L, Samaniego-Castruita D, White B, Chawla A, et al. Innate-like functions of natural killer $\mathrm{T}$ cell subsets result from highly divergent gene programs. Nat Immunol (2016) 17:728-39. doi:10.1038/ ni. 3437

19. Matsuda JL, Mallevaey T, Scott-Browne J, Gapin L. CD1d-restricted iNKT cells, the "Swiss-Army knife" of the immune system. Curr Opin Immunol (2008) 20:358-68. doi:10.1016/j.coi.2008.03.018

20. Stober D, Jomantaite I, Schirmbeck R, Reimann J. NKT cells provide help for dendritic cell-dependent priming of MHC class I-restricted CD8+ T cells in vivo. J Immunol (2003) 170:2540-8. doi:10.4049/jimmunol.170.5.2540

21. Paget C, Chow MT, Duret H, Mattarollo SR, Smyth MJ. Role of $\gamma \delta$ T cells in $\alpha$-galactosylceramide-mediated immunity. J Immunol (2012) 188:3928-39. doi:10.4049/jimmunol.1103582

22. De Santo C, Arscott R, Booth S, Karydis I, Jones M, Asher R, et al. Invariant NKT cells modulate the suppressive activity of IL-10-secreting neutrophils differentiated with serum amyloid A. Nat Immunol (2010) 11:1039-46. doi:10.1038/ni.1942

23. Singh N, Hong S, Scherer DC, Serizawa I, Burdin N, Kronenberg M, et al. Cutting edge: activation of NK T cells by CD1d and alpha-galactosylceramide directs conventional $\mathrm{T}$ cells to the acquisition of a Th2 phenotype. J Immunol (1999) 163:2373-7.

24. Carnaud C, Lee D, Donnars O, Park SH, Beavis A, Koezuka Y, et al. Cutting edge: cross-talk between cells of the innate immune system: NKT cells rapidly activate NK cells. J Immunol (1999) 163:4647-50.

25. Nieuwenhuis EES, Matsumoto T, Exley M, Schleipman RA, Glickman J, Bailey DT, et al. CD1d-dependent macrophage-mediated clearance of Pseudomonas aeruginosa from lung. Nat Med (2002) 8:588-93. doi:10.1038/ nm0602-588

26. Galli G, Pittoni P, Tonti E, Malzone C, Uematsu Y, Tortoli M, et al. Invariant NKT cells sustain specific B cell responses and memory. Proc Natl Acad Sci US A (2007) 104:3984-9. doi:10.1073/pnas.0700191104

27. Hermans IF, Silk JD, Gileadi U, Salio M, Mathew B, Ritter G, et al. NKT cells enhance CD4+ and CD8+ T cell responses to soluble antigen in vivo through direct interaction with dendritic cells. J Immunol (2003) 171: 5140-7. doi:10.4049/jimmunol.171.10.5140

28. Kitamura H, Iwakabe K, Yahata T, Nishimura S, Ohta A, Ohmi Y, et al. The natural killer T (NKT) cell ligand alpha-galactosylceramide demonstrates its immunopotentiating effect by inducing interleukin (IL)-12 production by dendritic cells and IL-12 receptor expression on NKT cells. J Exp Med (1999) 189:1121-8. doi:10.1084/jem.189.7.1121

29. Metelitsa LS, Naidenko OV, Kant A, Wu HW, Loza MJ, Perussia B, et al. Human NKT cells mediate antitumor cytotoxicity directly by recognizing target cell CD1d with bound ligand or indirectly by producing IL-2 to activate NK cells. JImmunol (2001) 167:3114-22. doi:10.4049/ jimmunol.167.6.3114

30. Macho Fernandez E, Chang J, Fontaine J, Bialecki E, Rodriguez F, Werkmeister E, et al. Activation of invariant natural killer $\mathrm{T}$ lymphocytes in response to the $\alpha$-galactosylceramide analogue KRN7000 encapsulated in PLGAbased nanoparticles and microparticles. Int J Pharm (2012) 423:45-54. doi:10.1016/j.ijpharm.2011.04.068

31. Dhodapkar MV, Kumar V. Type II NKT cells and their emerging role in health and disease. J Immunol (2017) 198:1015-21. doi:10.4049/jimmunol. 1601399

32. Exley MA, Tahir SM, Cheng O, Shaulov A, Joyce R, Avigan D, et al. A major fraction of human bone marrow lymphocytes are Th2-like CD1d-reactive $\mathrm{T}$ cells that can suppress mixed lymphocyte responses. J Immunol (2001) 167:5531-4. doi:10.4049/jimmunol.167.10.5531

33. Van Rhijn I, Young DC, Im JS, Levery SB, Illarionov PA, Besra GS, et al. CD1d-restricted T cell activation by nonlipidic small molecules. Proc Natl Acad Sci U S A (2004) 101:13578-83. doi:10.1073/pnas.0402838101

34. Patel O, Pellicci DG, Gras S, Sandoval-Romero ML, Uldrich AP, Mallevaey T, et al. Recognition of CD1d-sulfatide mediated by a type II natural killer $\mathrm{T}$ cell antigen receptor. Nat Immunol (2012) 13:857-63. doi:10.1038/ ni. 2372

35. Tatituri RVV, Watts GFM, Bhowruth V, Barton N, Rothchild A, Hsu F-F, et al. Recognition of microbial and mammalian phospholipid antigens by NKT cells with diverse TCRs. Proc Natl Acad Sci U S A (2013) 110:1827-32. doi:10.1073/pnas.1220601110

36. Arrenberg P, Halder R, Dai Y, Maricic I, Kumar V. Oligoclonality and innate-like features in the TCR repertoire of type II NKT cells reactive to a beta-linked self-glycolipid. Proc Natl Acad Sci U S A (2010) 107:10984-9. doi:10.1073/pnas.1000576107

37. Maricic I, Girardi E, Zajonc DM, Kumar V. Recognition of lysophosphatidylcholine by type II NKT cells and protection from an inflammatory liver disease. J Immunol (2014) 193:4580-9. doi:10.4049/jimmunol.1400699

38. Girardi E, Maricic I, Wang J, Mac T-T, Iyer P, Kumar V, et al. Type II natural killer $\mathrm{T}$ cells use features of both innate-like and conventional $\mathrm{T}$ cells to recognize sulfatide self antigens. Nat Immunol (2012) 13:851-6. doi:10.1038/ ni.2371

39. Koay H-F, Gherardin NA, Enders A, Loh L, Mackay LK, Almeida CF, et al. A three-stage intrathymic development pathway for the mucosal-associated invariant T cell lineage. Nat Immunol (2016) 17:1300-11. doi:10.1038/ ni. 3565

40. Bedel R, Matsuda JL, Brigl M, White J, Kappler J, Marrack P, et al. Lower TCR repertoire diversity in Traj18-deficient mice. Nat Immunol (2012) 13:705-6. doi:10.1038/ni.2347

41. Zhang J, Bedel R, Krovi SH, Tuttle KD, Zhang B, Gross J, et al. Mutation of the Traj18 gene segment using TALENs to generate natural killer T cell deficient mice. Sci Rep (2016) 6:27375. doi:10.1038/srep27375

42. Chandra S, Zhao M, Budelsky A, de Mingo Pulido A, Day J, Fu Z, et al. A new mouse strain for the analysis of invariant NKT cell function. Nat Immunol (2015) 16:799-800. doi:10.1038/ni.3203

43. Dasgupta S, Kumar V. Type II NKT cells: a distinct CD1d-restricted immune regulatory NKT cell subset. Immunogenetics (2016) 68:665-76. doi:10.1007/ s00251-016-0930-1

44. Macho-Fernandez E, Brigl M. The extended family of CD1d-restricted NKT cells: sifting through a mixed bag of TCRs, antigens, and functions. Front Immunol (2015) 6:362. doi:10.3389/fimmu.2015.00362

45. Pellicci DG, Uldrich AP. Unappreciated diversity within the pool of CD1d-restricted T cells. Semin Cell Dev Biol (2017). doi:10.1016/j.semcdb. 2017.11.031 
46. Uldrich AP, Patel O, Cameron G, Pellicci DG, Day EB, Sullivan LC, et al. A semi-invariant $V \alpha 10+T$ cell antigen receptor defines a population of natural killer $\mathrm{T}$ cells with distinct glycolipid antigen-recognition properties. Nat Immunol (2011) 12:616-23. doi:10.1038/ni.2051

47. Le Nours J, Praveena T, Pellicci DG, Gherardin NA, Ross FJ, Lim RT, et al. Atypical natural killer T-cell receptor recognition of CD1d-lipid antigens. Nat Commun (2016) 7:10570. doi:10.1038/ncomms10570

48. Bai L, Picard D, Anderson B, Chaudhary V, Luoma A, Jabri B, et al. The majority of CD1d-sulfatide-specific T cells in human blood use a semiinvariant V81 TCR. Eur J Immunol (2012) 42:2505-10. doi:10.1002/eji. 201242531

49. Uldrich AP, Le Nours J, Pellicci DG, Gherardin NA, McPherson KG, Lim RT, et al. CD1d-lipid antigen recognition by the $\gamma \delta$ TCR. Nat Immunol (2013) 14:1137-45. doi:10.1038/ni.2713

50. Luoma AM, Castro CD, Mayassi T, Bembinster LA, Bai L, Picard D, et al. Crystal structure of V81 T cell receptor in complex with CD1d-sulfatide shows MHC-like recognition of a self-lipid by human $\gamma \delta$ T cells. Immunity (2013) 39:1032-42. doi:10.1016/j.immuni.2013.11.001

51. Russano AM, Agea E, Corazzi L, Postle AD, De Libero G, Porcelli S, et al. Recognition of pollen-derived phosphatidyl-ethanolamine by human CD1drestricted gamma delta T cells. J Allergy Clin Immunol (2006) 117:1178-84. doi:10.1016/j.jaci.2006.01.001

52. Dieudé M, Striegl H, Tyznik AJ, Wang J, Behar SM, Piccirillo CA, et al. Cardiolipin binds to CD1d and stimulates CD1d-restricted $\gamma \delta \mathrm{T}$ cells in the normal murine repertoire. J Immunol (2011) 186:4771-81. doi:10.4049/ jimmunol.1000921

53. Pellicci DG, Uldrich AP, Le Nours J, Ross F, Chabrol E, Eckle SBG, et al. The molecular bases of $\delta / \alpha \beta \mathrm{T}$ cell-mediated antigen recognition. J Exp Med (2014) 211:2599-615. doi:10.1084/jem.20141764

54. Treiner E, Duban L, Bahram S, Radosavljevic M, Wanner V, Tilloy F, et al. Selection of evolutionarily conserved mucosal-associated invariant $\mathrm{T}$ cells by MR1. Nature (2003) 422:164-9. doi:10.1038/nature01433

55. Tilloy F, Treiner E, Park SH, Garcia C, Lemonnier F, de la Salle H, et al. An invariant $\mathrm{T}$ cell receptor alpha chain defines a novel TAP-independent major histocompatibility complex class Ib-restricted alpha/beta $\mathrm{T}$ cell subpopulation in mammals. J Exp Med (1999) 189:1907-21. doi:10.1084/ jem.189.12.1907

56. Tang X-Z, Jo J, Tan AT, Sandalova E, Chia A, Tan KC, et al. IL-7 licenses activation of human liver intrasinusoidal mucosal-associated invariant T cells. J Immunol (2013) 190:3142-52. doi:10.4049/jimmunol.1203218

57. Dusseaux M, Martin E, Serriari N, Péguillet I, Premel V, Louis D, et al. Human MAIT cells are xenobiotic-resistant, tissue-targeted, CD161hi IL-17-secreting T cells. Blood (2011) 117:1250-9. doi:10.1182/blood-2010-08-303339

58. Reantragoon R, Corbett AJ, Sakala IG, Gherardin NA, Furness JB, Chen Z, et al. Antigen-loaded MR1 tetramers define T cell receptor heterogeneity in mucosal-associated invariant T cells. J Exp Med (2013) 210:2305-20. doi:10.1084/jem. 20130958

59. Eckle SBG, Birkinshaw RW, Kostenko L, Corbett AJ, McWilliam HEG, Reantragoon $\mathrm{R}$, et al. A molecular basis underpinning the $\mathrm{T}$ cell receptor heterogeneity of mucosal-associated invariant T cells. J Exp Med (2014) 211:1585-600. doi:10.1084/jem.20140484

60. Ben Youssef G, Tourret M, Salou M, Ghazarian L, Houdouin V, Mondot S, et al. Ontogeny of human mucosal-associated invariant $\mathrm{T}$ cells and related T cell subsets. J Exp Med (2018) 215:459-79. doi:10.1084/jem.20171739

61. Gherardin NA, Keller AN, Woolley RE, Le Nours J, Ritchie DS, Neeson PJ, et al. Diversity of T cells restricted by the MHC class I-related molecule MR1 facilitates differential antigen recognition. Immunity (2016) 44:32-45. doi:10.1016/j.immuni.2015.12.005

62. Lepore M, Kalinichenko A, Calogero S, Kumar P, Paleja B, Schmaler M, et al. Functionally diverse human $\mathrm{T}$ cells recognize non-microbial antigens presented by MR1. Elife (2017) 6:ii:e24476. doi:10.7554/eLife.24476

63. Meermeier EW, Laugel BF, Sewell AK, Corbett AJ, Rossjohn J, McCluskey J, et al. Human TRAV1-2-negative MR1-restricted T cells detect $S$. pyogenes and alternatives to MAIT riboflavin-based antigens. Nat Commun (2016) 7:12506. doi:10.1038/ncomms 12506

64. Kjer-Nielsen L, Patel O, Corbett AJ, Le Nours J, Meehan B, Liu L, et al. MR1 presents microbial vitamin B metabolites to MAIT cells. Nature (2012) 491:717-23. doi:10.1038/nature11605
65. Corbett AJ, Eckle SBG, Birkinshaw RW, Liu L, Patel O, Mahony J, et al. T-cell activation by transitory neo-antigens derived from distinct microbial pathways. Nature (2014) 509:361-5. doi:10.1038/nature13160

66. Soudais C, Samassa F, Sarkis M, Le Bourhis L, Bessoles S, Blanot D, et al. In vitro and in vivo analysis of the Gram-negative bacteria-derived riboflavin precursor derivatives activating mouse MAIT cells. J Immunol (2015) 194:4641-9. doi:10.4049/jimmunol.1403224

67. Rahimpour A, Koay HF, Enders A, Clanchy R, Eckle SBG, Meehan B, et al. Identification of phenotypically and functionally heterogeneous mouse mucosal-associated invariant T cells using MR1 tetramers. J Exp Med (2015) 212:1095-108. doi:10.1084/jem.20142110

68. Loh L, Wang Z, Sant S, Koutsakos M, Jegaskanda S, Corbett AJ, et al. Human mucosal-associated invariant $\mathrm{T}$ cells contribute to antiviral influenza immunity via IL-18-dependent activation. Proc Natl Acad Sci U S A (2016) 113: 10133-8. doi:10.1073/pnas.1610750113

69. Le Bourhis L, Martin E, Péguillet I, Guihot A, Froux N, Coré M, et al. Antimicrobial activity of mucosal-associated invariant T cells. Nat Immunol (2010) 11:701-8. doi:10.1038/ni.1890

70. Salio M, Silk JD, Jones EY, Cerundolo V. Biology of CD1- and MR1-restricted T cells. Annu Rev Immunol (2014) 32:323-66. doi:10.1146/annurev-immunol032713-120243

71. Gold MC, Cerri S, Smyk-Pearson S, Cansler ME, Vogt TM, Delepine J, et al. Human mucosal associated invariant $\mathrm{T}$ cells detect bacterially infected cells. PLoS Biol (2010) 8:e1000407. doi:10.1371/journal.pbio. 1000407

72. Lepore M, Kalinichenko A, Kalinicenko A, Colone A, Paleja B, Singhal A, et al. Parallel T-cell cloning and deep sequencing of human MAIT cells reveal stable oligoclonal TCR $\beta$ repertoire. Nat Commun (2014) 5:3866. doi:10.1038/ ncomms 4866

73. Kawachi I, Maldonado J, Strader C, Gilfillan S. MR1-restricted V alpha 19i mucosal-associated invariant $\mathrm{T}$ cells are innate $\mathrm{T}$ cells in the gut lamina propria that provide a rapid and diverse cytokine response. J Immunol (2006) 176:1618-27. doi:10.4049/jimmunol.176.3.1618

74. Cui Y, Franciszkiewicz K, Mburu YK, Mondot S, Le Bourhis L, Premel $\mathrm{V}$, et al. Mucosal-associated invariant $\mathrm{T}$ cell-rich congenic mouse strain allows functional evaluation. J Clin Invest (2015) 125:4171-85. doi:10.1172/ JCI82424

75. van Wilgenburg B, Scherwitzl I, Hutchinson EC, Leng T, Kurioka A, Kulicke C, et al. MAIT cells are activated during human viral infections. Nat Commun (2016) 7:11653. doi:10.1038/ncomms11653

76. Paquin-Proulx D, Avelino-Silva VI, Santos BAN, Silveira Barsotti N, Siroma F, Fernandes Ramos J, et al. MAIT cells are activated in acute dengue virus infection and after in vitro Zika virus infection. PLoS Negl Trop Dis (2018) 12:e0006154. doi:10.1371/journal.pntd.0006154

77. Fernandez CS, Amarasena T, Kelleher AD, Rossjohn J, McCluskey J, Godfrey DI, et al. MAIT cells are depleted early but retain functional cytokine expression in HIV infection. Immunol Cell Biol (2015) 93:177-88. doi:10.1038/ icb.2014.91

78. Leeansyah E, Svärd J, Dias J, Buggert M, Nyström J, Quigley MF, et al. Arming of MAIT cell cytolytic antimicrobial activity is induced by IL-7 and defective in HIV-1 infection. PLoS Pathog (2015) 11:e1005072. doi:10.1371/ journal.ppat.1005072

79. Sundström P, Ahlmanner F, Akéus P, Sundquist M, Alsén S, Yrlid U, et al. Human mucosa-associated invariant $\mathrm{T}$ cells accumulate in colon adenocarcinomas but produce reduced amounts of IFN- $\gamma$. JImmunol (2015) 195:3472-81. doi:10.4049/jimmunol.1500258

80. Won EJ, Ju JK, Cho Y-N, Jin H-M, Park K-J, Kim T-J, et al. Clinical relevance of circulating mucosal-associated invariant $\mathrm{T}$ cell levels and their anticancer activity in patients with mucosal-associated cancer. Oncotarget (2016) 7:76274-90. doi:10.18632/oncotarget.11187

81. Gherardin NA, Loh L, Admojo L, Davenport AJ, Richardson K, Rogers A, et al. Enumeration, functional responses and cytotoxic capacity of MAIT cells in newly diagnosed and relapsed multiple myeloma. Sci Rep (2018) 8:4159. doi:10.1038/s41598-018-22130-1

82. Zabijak L, Attencourt C, Guignant C, Chatelain D, Marcelo P, Marolleau J-P, et al. Increased tumor infiltration by mucosal-associated invariant $\mathrm{T}$ cells correlates with poor survival in colorectal cancer patients. Cancer Immunol Immunother (2015) 64:1601-8. doi:10.1007/s00262-015-1764-7 
83. Magalhaes I, Pingris K, Poitou C, Bessoles S, Venteclef N, Kiaf B, et al. Mucosal-associated invariant $\mathrm{T}$ cell alterations in obese and type 2 diabetic patients. J Clin Invest (2015) 125:1752-62. doi:10.1172/JCI78941

84. Rouxel O, Da Silva J, Beaudoin L, Nel I, Tard C, Cagninacci L, et al. Cytotoxic and regulatory roles of mucosal-associated invariant $\mathrm{T}$ cells in type 1 diabetes. Nat Immunol (2017) 18:1321-31. doi:10.1038/ni.3854

85. Serriari N-E, Eoche M, Lamotte L, Lion J, Fumery M, Marcelo P, et al. Innate mucosal-associated invariant T (MAIT) cells are activated in inflammatory bowel diseases. Clin Exp Immunol (2014) 176:266-74. doi:10.1111/ cei. 12277

86. Hiejima E, Kawai T, Nakase H, Tsuruyama T, Morimoto T, Yasumi T, et al. Reduced numbers and proapoptotic features of mucosal-associated invariant $\mathrm{T}$ cells as a characteristic finding in patients with inflammatory bowel disease. Inflamm Bowel Dis (2015) 21:1529-40. doi:10.1097/MIB.0000000000000397

87. Varelias A, Bunting MD, Ormerod KL, Koyama M, Olver SD, Straube J, et al. Recipient mucosal-associated invariant T cells control GVHD within the colon. J Clin Invest (2018) 128:1919-36. doi:10.1172/JCI91646

88. Kwon YS, Jin H-M, Cho Y-N, Kim M-J, Kang J-H, Jung H-J, et al. Mucosalassociated invariant $\mathrm{T}$ cell deficiency in chronic obstructive pulmonary disease. COPD (2016) 13:196-202. doi:10.3109/15412555.2015.1069806

89. Szabó M, Sárosi V, Balikó Z, Bodó K, Farkas N, Berki T, et al. Deficiency of innate-like $\mathrm{T}$ lymphocytes in chronic obstructive pulmonary disease. Respir Res (2017) 18:197. doi:10.1186/s12931-017-0671-1

90. Salou M, Nicol B, Garcia A, Baron D, Michel L, Elong-Ngono A, et al. Neuropathologic, phenotypic and functional analyses of mucosal associated invariant T cells in multiple sclerosis. Clin Immunol (2016) 166-167:1-11. doi:10.1016/j.clim.2016.03.014

91. Willing A, Jäger J, Reinhardt S, Kursawe N, Friese MA. Production of IL-17 by MAIT cells is increased in multiple sclerosis and is associated with IL-7 receptor expression. J Immunol (2018) 200:974-82. doi:10.4049/ jimmunol.1701213

92. Thanabalasuriar A, Neupane AS, Wang J, Krummel MF, Kubes P. iNKT cell emigration out of the lung vasculature requires neutrophils and monocytederived dendritic cells in inflammation. Cell Rep (2016) 16:3260-72. doi:10.1016/j.celrep.2016.07.052

93. Scanlon ST, Thomas SY, Ferreira CM, Bai L, Krausz T, Savage PB, et al. Airborne lipid antigens mobilize resident intravascular NKT cells to induce allergic airway inflammation. J Exp Med (2011) 208:2113-24. doi:10.1084/ jem.20110522

94. Lee YJ, Wang H, Starrett GJ, Phuong V, Jameson SC, Hogquist KA. Tissuespecific distribution of iNKT cells impacts their cytokine response. Immunity (2015) 43:566-78. doi:10.1016/j.immuni.2015.06.025

95. Olszak T, An D, Zeissig S, Vera MP, Richter J, Franke A, et al. Microbial exposure during early life has persistent effects on natural killer $\mathrm{T}$ cell function. Science (2012) 336:489-93. doi:10.1126/science.1219328

96. Dieli F, Taniguchi M, Kronenberg M, Sidobre S, Ivanyi J, Fattorini L, et al. An anti-inflammatory role for $\mathrm{V}$ alpha $14 \mathrm{NK}$ T cells in Mycobacterium bovis bacillus Calmette-Guérin-infected mice. J Immunol (2003) 171:1961-8. doi:10.4049/jimmunol.171.4.1961

97. Kawakami K, Kinjo Y, Uezu K, Miyagi K, Kinjo T, Yara S, et al. Interferongamma production and host protective response against Mycobacterium tuberculosis in mice lacking both IL-12p40 and IL-18. Microbes Infect (2004) 6: 339-49. doi:10.1016/j.micinf.2004.01.003

98. Emoto M, Emoto Y, Buchwalow IB, Kaufmann SH. Induction of IFN-gammaproducing CD4+ natural killer T cells by Mycobacterium bovis bacillus Calmette Guérin. Eur J Immunol (1999) 29:650-9. doi:10.1002/(SICI)1521-4141 (199902)29:02<650::AID-IMMU650>3.0.CO;2-M

99. Chiba A, Dascher CC, Besra GS, Brenner MB. Rapid NKT cell responses are self-terminating during the course of microbial infection. J Immunol (2008) 181:2292-302. doi:10.4049/jimmunol.181.4.2292

100. Sugawara I, Yamada H, Mizuno S, Li CY, Nakayama T, Taniguchi M. Mycobacterial infection in natural killer T cell knockout mice. Tuberculosis (Edinb) (2002) 82:97-104. doi:10.1054/tube.2002.0331

101. Kawakami K, Kinjo Y, Uezu K, Yara S, Miyagi K, Koguchi Y, et al. Minimal contribution of Valpha14 natural killer $\mathrm{T}$ cells to Th1 response and host resistance against mycobacterial infection in mice. Microbiol Immunol (2002) 46:207-10. doi:10.1111/j.1348-0421.2002.tb02687.x
102. Sköld M, Behar SM. Role of CD1d-restricted NKT cells in microbial immunity. Infect Immun (2003) 71:5447-55. doi:10.1128/IAI.71.10.5447-5455.2003

103. Sousa AO, Mazzaccaro RJ, Russell RG, Lee FK, Turner OC, Hong S, et al. Relative contributions of distinct MHC class I-dependent cell populations in protection to tuberculosis infection in mice. Proc Natl Acad Sci U S A (2000) 97:4204-8. doi:10.1073/pnas.97.8.4204

104. Szalay G, Zügel U, Ladel CH, Kaufmann SH. Participation of group 2 CD1 molecules in the control of murine tuberculosis. Microbes Infect (1999) 1:1153-7. doi:10.1016/S1286-4579(99)00248-8

105. Apostolou I, Takahama Y, Belmant C, Kawano T, Huerre M, Marchal G, et al. Murine natural killer T(NKT) cells [correction of natural killer cells] contribute to the granulomatous reaction caused by mycobacterial cell walls. Proc Natl Acad Sci U S A (1999) 96:5141-6. doi:10.1073/pnas.96.9.5141

106. Behar SM, Dascher CC, Grusby MJ, Wang CR, Brenner MB. Susceptibility of mice deficient in CD1D or TAP1 to infection with Mycobacterium tuberculosis. J Exp Med (1999) 189:1973-80. doi:10.1084/jem.189.12.1973

107. Chua W-J, Truscott SM, Eickhoff CS, Blazevic A, Hoft DF, Hansen TH. Polyclonal mucosa-associated invariant $\mathrm{T}$ cells have unique innate functions in bacterial infection. Infect Immun (2012) 80:3256-67. doi:10.1128/ IAI.00279-12

108. Hill TM, Gilchuk P, Cicek BB, Osina MA, Boyd KL, Durrant DM, et al. Border patrol gone awry: lung NKT cell activation by Francisella tularensis exacerbates tularemia-like disease. PLoS Pathog (2015) 11:e1004975. doi:10.1371/ journal.ppat.1004975

109. Meierovics A, Yankelevich W-JC, Cowley SC. MAIT cells are critical for optimal mucosal immune responses during in vivo pulmonary bacterial infection. Proc Natl Acad Sci U S A (2013) 110:E3119-28. doi:10.1073/ pnas. 1302799110

110. Meierovics AI, Cowley SC. MAIT cells promote inflammatory monocyte differentiation into dendritic cells during pulmonary intracellular infection. J Exp Med (2016) 213:2793-809. doi:10.1084/jem.20160637

111. Kawakami K, Yamamoto N, Kinjo Y, Miyagi K, Nakasone C, Uezu K, et al. Critical role of Valpha14+ natural killer T cells in the innate phase of host protection against Streptococcus pneumoniae infection. Eur J Immunol (2003) 33:3322-30. doi:10.1002/eji.200324254

112. Barthelemy A, Ivanov S, Fontaine J, Soulard D, Bouabe H, Paget C, et al. Influenza A virus-induced release of interleukin-10 inhibits the antimicrobial activities of invariant natural killer $\mathrm{T}$ cells during invasive pneumococcal superinfection. Mucosal Immunol (2017) 10:460-9. doi:10.1038/ mi.2016.49

113. Nakamatsu M, Yamamoto N, Hatta M, Nakasone C, Kinjo T, Miyagi K, et al. Role of interferon-gamma in Valpha14+ natural killer $\mathrm{T}$ cell-mediated host defense against Streptococcus pneumoniae infection in murine lungs. Microbes Infect (2007) 9:364-74. doi:10.1016/j.micinf.2006.12.003

114. Kinjo Y, Illarionov P, Vela JL, Pei B, Girardi E, Li X, et al. Invariant natural killer $\mathrm{T}$ cells recognize glycolipids from pathogenic Gram-positive bacteria. Nat Immunol (2011) 12:966-74. doi:10.1038/ni.2096

115. King IL, Amiel E, Tighe M, Mohrs K, Veerapen N, Besra G, et al. The mechanism of splenic invariant NKT cell activation dictates localization in vivo. J Immunol (2013) 191:572-82. doi:10.4049/jimmunol.1300299

116. Hartmann N, McMurtrey C, Sorensen ML, Huber ME, Kurapova R, Coleman FT, et al. Riboflavin metabolism variation among clinical isolates of Streptococcus pneumoniae results in differential activation of MAIT cells. Am J Respir Cell Mol Biol (2018) 58(6):767-76. doi:10.1165/rcmb.2017-0290OC

117. Kok WL, Denney L, Benam K, Cole S, Clelland C, McMichael AJ, et al. Pivotal advance: invariant NKT cells reduce accumulation of inflammatory monocytes in the lungs and decrease immune-pathology during severe influenza A virus infection. J Leukoc Biol (2012) 91:357-68. doi:10.1189/jlb. 0411184

118. Paget C, Ivanov S, Fontaine J, Blanc F, Pichavant M, Renneson J, et al. Potential role of invariant NKT cells in the control of pulmonary inflammation and $\mathrm{CD} 8+\mathrm{T}$ cell response during acute influenza A virus $\mathrm{H} 3 \mathrm{~N} 2$ pneumonia. J Immunol (2011) 186:5590-602. doi:10.4049/jimmunol.1002348

119. De Santo C, Salio M, Masri SH, Lee LY-H, Dong T, Speak AO, et al. Invariant NKT cells reduce the immunosuppressive activity of influenza A virusinduced myeloid-derived suppressor cells in mice and humans. J Clin Invest (2008) 118:4036-48. doi:10.1172/JCI36264 
120. Paget C, Ivanov S, Fontaine J, Renneson J, Blanc F, Pichavant M, et al. Interleukin-22 is produced by invariant natural killer $\mathrm{T}$ lymphocytes during influenza A virus infection: potential role in protection against lung epithelial damages. J Biol Chem (2012) 287:8816-29. doi:10.1074/ jbc.M111.304758

121. Organization WH. Global Tuberculosis Report 2015. World Health Organization (2015). Available from: http://apps.who.int/iris/handle/10665/191102 (Accessed: May 17, 2018).

122. Houben RMGJ, Dodd PJ. The global burden of latent tuberculosis infection: a re-estimation using mathematical modelling. PLoS Med (2016) 13:e1002152. doi:10.1371/journal.pmed.1002152

123. Getahun H, Chaisson RE, Raviglione M. Latent Mycobacterium tuberculosis infection. N Engl J Med (2015) 373:1179-80. doi:10.1056/NEJMc1508223

124. Calmette A. Preventive vaccination against tuberculosis with BCG. Proc $R$ Soc Med (1931) 24:1481-90.

125. Global Tuberculosis Report 2014. (2015). Available from: http://apps.who. int/medicinedocs/en/d/Js21634en/ (Accessed: May 17, 2018)

126. Sada-Ovalle I, Chiba A, Gonzales A, Brenner MB, Behar SM. Innate invariant NKT cells recognize Mycobacterium tuberculosis-infected macrophages, produce interferon-gamma, and kill intracellular bacteria. PLoS Pathog (2008) 4:e1000239. doi:10.1371/journal.ppat.1000239

127. Rothchild AC, Jayaraman P, Nunes-Alves C, Behar SM. iNKT cell production of GM-CSF controls Mycobacterium tuberculosis. PLoS Pathog (2014) 10:e1003805. doi:10.1371/journal.ppat.1003805

128. Fischer K, Scotet E, Niemeyer M, Koebernick H, Zerrahn J, Maillet S, et al. Mycobacterial phosphatidylinositol mannoside is a natural antigen for CD1d-restricted T cells. Proc Natl Acad Sci U S A (2004) 101:10685-90. doi:10.1073/pnas.0403787101

129. Montoya CJ, Cataño JC, Ramirez Z, Rugeles MT, Wilson SB, Landay AL. Invariant NKT cells from HIV-1 or Mycobacterium tuberculosis-infected patients express an activated phenotype. Clin Immunol (2008) 127:1-6. doi:10.1016/j.clim.2007.12.006

130. Snyder-Cappione JE, Nixon DF, Loo CP, Chapman JM, Meiklejohn DA, Melo FF, et al. Individuals with pulmonary tuberculosis have lower levels of circulating CD1d-restricted NKT cells. J Infect Dis (2007) 195:1361-4. doi:10.1086/513567

131. Sutherland JS, Jeffries DJ, Donkor S, Walther B, Hill PC, Adetifa IMO, et al. High granulocyte/lymphocyte ratio and paucity of NKT cells defines TB disease in a TB-endemic setting. Tuberculosis (Edinb) (2009) 89:398-404. doi:10.1016/j.tube.2009.07.004

132. Berzins SP, Smyth MJ, Baxter AG. Presumed guilty: natural killer T cell defects and human disease. Nat Rev Immunol (2011) 11:131-42. doi:10.1038/ nri2904

133. Im JS, Kang T-J, Lee S-B, Kim C-H, Lee S-H, Venkataswamy MM, et al. Alteration of the relative levels of iNKT cell subsets is associated with chronic mycobacterial infections. Clin Immunol (2008) 127:214-24. doi:10.1016/j. clim.2007.12.005

134. Veenstra H, Baumann R, Carroll NM, Lukey PT, Kidd M, Beyers N, et al. Changes in leucocyte and lymphocyte subsets during tuberculosis treatment; prominence of CD3dimCD56+ natural killer $\mathrm{T}$ cells in fast treatment responders. Clin Exp Immunol (2006) 145:252-60. doi:10.1111/j. 1365-2249.2006.03144.x

135. Li Z, Yang B, Zhang Y, Ma J, Chen X, Lao S, et al. Mycobacterium tuberculosisspecific memory NKT cells in patients with tuberculous pleurisy. J Clin Immunol (2014) 34:979-90. doi:10.1007/s10875-014-0090-8

136. Singh A, Dey AB, Mohan A, Mitra DK. Programmed death-1 receptor suppresses $\gamma$-IFN producing NKT cells in human tuberculosis. Tuberculosis (Edinb) (2014) 94:197-206. doi:10.1016/j.tube.2014.01.005

137. Kee S-J, Kwon Y-S, Park Y-W, Cho Y-N, Lee S-J, Kim T-J, et al. Dysfunction of natural killer T cells in patients with active Mycobacterium tuberculosis infection. Infect Immun (2012) 80:2100-8. doi:10.1128/IAI.06018-11

138. Wu C, Li Z, Fu X, Yu S, Lao S, Yang B. Antigen-specific human NKT cells from tuberculosis patients produce IL-21 to help B cells for the production of immunoglobulins. Oncotarget (2015) 6:28633-45. doi:10.18632/ oncotarget.5764

139. Sada-Ovalle I, Sköld M, Tian T, Besra GS, Behar SM. Alpha-galactosylceramide as a therapeutic agent for pulmonary Mycobacterium tuberculosis infection.
Am JRespir Crit Care Med (2010) 182:841-7. doi:10.1164/rccm.20091219210C

140. Chackerian A, Alt J, Perera V, Behar SM. Activation of NKT cells protects mice from tuberculosis. Infect Immun (2002) 70:6302-9. doi:10.1128/IAI. 70.11.6302-6309.2002

141. Venkataswamy MM, Baena A, Goldberg MF, Bricard G, Im JS, Chan J, et al. Incorporation of NKT cell-activating glycolipids enhances immunogenicity and vaccine efficacy of Mycobacterium bovis bacillus Calmette-Guerin. J Immunol (2009) 183:1644-56. doi:10.4049/jimmunol.0900858

142. Khan A, Singh S, Galvan G, Jagannath C, Sastry KJ. Prophylactic sublingual immunization with mycobacterium tuberculosis subunit vaccine incorporating the natural killer $\mathrm{T}$ cell agonist alpha-galactosylceramide enhances protective immunity to limit pulmonary and extra-pulmonary bacterial burden in mice. Vaccines (Basel) (2017) 5:47-59. doi:10.3390/ vaccines5040047

143. Cavallo GP, Elia M, Giordano D, Baldi C, Cammarota R. Decrease of specific and total IgE levels in allergic patients after BCG vaccination: preliminary report. Arch Otolaryngol Head Neck Surg (2002) 128:1058-60. doi:10.1001/ archotol.128.9.1058

144. Herz U, Gerhold K, Grüber C, Braun A, Wahn U, Renz H, et al. BCG infection suppresses allergic sensitization and development of increased airway reactivity in an animal model. J Allergy Clin Immunol (1998) 102:867-74. doi:10.1016/S0091-6749(98)70030-2

145. Harada M, Magara-Koyanagi K, Watarai H, Nagata Y, Ishii Y, Kojo S, et al. IL-21-induced Bepsilon cell apoptosis mediated by natural killer T cells suppresses IgE responses. J Exp Med (2006) 203:2929-37. doi:10.1084/ jem.20062206

146. Kwon Y-S, Cho Y-N, Kim M-J, Jin H-M, Jung H-J, Kang J-H, et al. Mucosalassociated invariant $\mathrm{T}$ cells are numerically and functionally deficient in patients with mycobacterial infection and reflect disease activity. Tuberculosis (Edinb) (2015) 95:267-74. doi:10.1016/j.tube.2015.03.004

147. Jiang J, Wang X, An H, Yang B, Cao Z, Liu Y, et al. Mucosal-associated invariant $\mathrm{T}$-cell function is modulated by programmed death-1 signaling in patients with active tuberculosis. Am J Respir Crit Care Med (2014) 190:329-39. doi:10.1164/rccm.201401-0106OC

148. Gold MC, Eid T, Smyk-Pearson S, Eberling Y, Swarbrick GM, Langley SM, et al. Human thymic MR1-restricted MAIT cells are innate pathogenreactive effectors that adapt following thymic egress. Mucosal Immunol (2013) 6:35-44. doi:10.1038/mi.2012.45

149. Harriff MJ, Cansler ME, Toren KG, Canfield ET, Kwak S, Gold MC, et al. Human lung epithelial cells contain Mycobacterium tuberculosis in a late endosomal vacuole and are efficiently recognized by $\mathrm{CD}^{+} \mathrm{T}$ cells. PLoS One (2014) 9:e97515. doi:10.1371/journal.pone.0097515

150. Oyston PCF. Francisella tularensis: unravelling the secrets of an intracellular pathogen. J Med Microbiol (2008) 57:921-30. doi:10.1099/jmm.0.2008/ 000653-0

151. Ellis J, Oyston PCF, Green M, Titball RW. Tularemia. Clin Microbiol Rev (2002) 15:631-46. doi:10.1128/CMR.15.4.631-646.2002

152. Keim P, Johansson A, Wagner DM. Molecular epidemiology, evolution, and ecology of Francisella. Ann N Y Acad Sci (2007) 1105:30-66. doi:10.1196/ annals.1409.011

153. McLendon MK, Apicella MA, Allen L-AH. Francisella tularensis: taxonomy, genetics, and immunopathogenesis of a potential agent of biowarfare. Annu Rev Microbiol (2006) 60:167-85. doi:10.1146/annurev.micro.60.080805.142126

154. Sharma J, Li Q, Mishra BB, Pena C, Teale JM. Lethal pulmonary infection with Francisella novicida is associated with severe sepsis. J Leukoc Biol (2009) 86:491-504. doi:10.1189/jlb.1208728

155. Bendelac A, Hunziker RD, Lantz O. Increased interleukin 4 and immunoglobulin E production in transgenic mice overexpressing NK1 T cells. J Exp Med (1996) 184:1285-93. doi:10.1084/jem.184.4.1285

156. Cowley SC, Meierovics AI, Frelinger JA, Iwakura Y, Elkins KL. Lung CD4-CD8-double-negative T cells are prominent producers of IL-17A and IFN-gamma during primary respiratory murine infection with Francisella tularensis live vaccine strain. J Immunol (2010) 184:5791-801. doi:10.4049/ jimmunol.1000362

157. Jesteadt E, Zhang I, Yu H, Meierovics A, Chua Yankelevich W-J, Cowley S. Interleukin-18 is critical for mucosa-associated invariant $\mathrm{T}$ cell gamma 
interferon responses to Francisella species in vitro but not in vivo. Infect Immun (2018) 86:e00117-18. doi:10.1128/IAI.00117-18

158. Weiser JN, Ferreira DM, Paton JC. Streptococcus pneumoniae: transmission, colonization and invasion. Nat Rev Microbiol (2018) 16:355-67. doi:10.1038/ s41579-018-0001-8

159. Morris DE, Cleary DW, Clarke SC. Secondary bacterial infections associated with Influenza Pandemics. Front Microbiol (2017) 8:1041. doi:10.3389/fmicb. 2017.01041

160. Domenech A, Ardanuy C, Tercero A, García-Somoza D, Santos S, Liñares J. Dynamics of the pneumococcal population causing acute exacerbations in COPD patients in a Barcelona hospital (2009-12): comparison with 2001-04 and 2005-08 periods. J Antimicrob Chemother (2014) 69:932-9. doi:10.1093/ $\mathrm{jac} / \mathrm{dkt} 476$

161. Moffitt K, Malley R. Rationale and prospects for novel pneumococcal vaccines. Hum Vaccin Immunother (2016) 12:383-92. doi:10.1080/21645515. 2015.1087625

162. Bröker M, Berti F, Schneider J, Vojtek I. Polysaccharide conjugate vaccine protein carriers as a "neglected valency" - potential and limitations. Vaccine (2017) 35:3286-94. doi:10.1016/j.vaccine.2017.04.078

163. Cherazard R, Epstein M, Doan T-L, Salim T, Bharti S, Smith MA. Antimicrobial resistant Streptococcus pneumoniae: prevalence, mechanisms, and clinical implications. Am J Ther (2017) 24:e361-9. doi:10.1097/MJT.0000000000000551

164. Ivanov S, Fontaine J, Paget C, Macho Fernandez E, Van Maele L, Renneson J, et al. Key role for respiratory CD103(+) dendritic cells, IFN- $\gamma$, and IL-17 in protection against Streptococcus pneumoniae infection in response to $\alpha$ galactosylceramide. J Infect Dis (2012) 206:723-34. doi:10.1093/infdis/jis413

165. Shimamura $M$, Yamamura $M$, Nabeshima $T$, Kitano N, van den Elzen $P$, Yesilkaya $\mathrm{H}$, et al. Activation of invariant natural killer T cells stimulated with microbial $\alpha$-mannosyl glycolipids. Sci Rep (2017) 7:9703. doi:10.1038/ s41598-017-10309-x

166. Leadbetter EA, Brigl M, Illarionov P, Cohen N, Luteran MC, Pillai S, et al. NK T cells provide lipid antigen-specific cognate help for B cells. Proc Natl Acad Sci U S A (2008) 105:8339-44. doi:10.1073/pnas.0801375105

167. Miyasaka T, Akahori Y, Toyama M, Miyamura N, Ishii K, Saijo S, et al. Dectin-2-dependent NKT cell activation and serotype-specific antibody production in mice immunized with pneumococcal polysaccharide vaccine. PLoS One (2013) 8:e78611. doi:10.1371/journal.pone.0078611

168. Kobrynski LJ, Sousa AO, Nahmias AJ, Lee FK. Cutting edge: antibody production to pneumococcal polysaccharides requires CD1 molecules and CD8+ T cells. J Immunol (2005) 174:1787-90. doi:10.4049/jimmunol.174.4.1787

169. Bai L, Deng S, Reboulet R, Mathew R, Teyton L, Savage PB, et al. Natural killer T (NKT)-B-cell interactions promote prolonged antibody responses and long-term memory to pneumococcal capsular polysaccharides. Proc Natl Acad Sci U S A (2013) 110:16097-102. doi:10.1073/pnas.1303218110

170. Deng S, Bai L, Reboulet R, Matthew R, Engler DA, Teyton L, et al. A peptidefree, liposome-based oligosaccharide vaccine, adjuvanted with a natural killer $\mathrm{T}$ cell antigen, generates robust antibody responses in vivo. Chem Sci (2014) 5:1437-41. doi:10.1039/C3SC53471E

171. Thorburn AN, O'Sullivan BJ, Thomas R, Kumar RK, Foster PS, Gibson PG, et al. Pneumococcal conjugate vaccine-induced regulatory T cells suppress the development of allergic airways disease. Thorax (2010) 65:1053-60. doi:10.1136/thx.2009.131508

172. Preston JA, Thorburn AN, Starkey MR, Beckett EL, Horvat JC, Wade MA, et al. Streptococcus pneumoniae infection suppresses allergic airways disease by inducing regulatory T-cells. Eur Respir J (2011) 37:53-64. doi:10.1183/ 09031936.00049510

173. Preston JA, Essilfie A-T, Horvat JC, Wade MA, Beagley KW, Gibson PG, et al. Inhibition of allergic airways disease by immunomodulatory therapy with whole killed Streptococcus pneumoniae. Vaccine (2007) 25:8154-62. doi:10.1016/j.vaccine.2007.09.034

174. Thorburn AN, Foster PS, Gibson PG, Hansbro PM. Components of Streptococcus pneumoniae suppress allergic airways disease and NKT cells by inducing regulatory T cells. J Immunol (2012) 188:4611-20. doi:10.4049/jimmunol. 1101299

175. Tettelin H, Nelson KE, Paulsen IT, Eisen JA, Read TD, Peterson S, et al. Complete genome sequence of a virulent isolate of Streptococcus pneumoniae. Science (2001) 293:498-506. doi:10.1126/science.1061217

176. Lanie JA, Ng W-L, Kazmierczak KM, Andrzejewski TM, Davidsen TM, Wayne KJ, et al. Genome sequence of Avery's virulent serotype 2 strain
D39 of Streptococcus pneumoniae and comparison with that of unencapsulated laboratory strain R6. J Bacteriol (2007) 189:38-51. doi:10.1128/JB. 01148-06

177. Kurioka A, van Wilgenburg B, Javan RR, Hoyle R, van Tonder AJ, Harrold CL, et al. Diverse Streptococcus pneumoniae strains drive a mucosal-associated invariant T-cell response through major histocompatibility complex class I-related molecule-dependent and cytokine-driven pathways. J Infect Dis (2018) 217:988-99. doi:10.1093/infdis/jix647

178. Hassane M, Demon D, Soulard D, Fontaine J, Keller LE, Patin EC, et al. Neutrophilic NLRP3 inflammasome-dependent IL-1 $\beta$ secretion regulates the $\gamma \delta \mathrm{T} 17$ cell response in respiratory bacterial infections. Mucosal Immunol (2017) 10:1056-68. doi:10.1038/mi.2016.113

179. Cao J, Wang D, Xu F, Gong Y, Wang H, Song Z, et al. Activation of IL-27 signalling promotes development of postinfluenza pneumococcal pneumonia. EMBO Mol Med (2014) 6:120-40. doi:10.1002/emmm.201302890

180. Grimaldi D, Le Bourhis L, Sauneuf B, Dechartres A, Rousseau C, Ouaaz F, et al. Specific MAIT cell behaviour among innate-like T lymphocytes in critically ill patients with severe infections. Intensive Care Med (2014) 40:192-201. doi:10.1007/s00134-013-3163-x

181. Iwasaki A, Pillai PS. Innate immunity to influenza virus infection. Nat Rev Immunol (2014) 14:315-28. doi:10.1038/nri3665

182. Monto AS. Epidemiology of influenza. Vaccine (2008) 26(Suppl 4):D45-8. doi:10.1016/j.vaccine.2008.07.066

183. Palese P. Influenza: old and new threats. Nat Med (2004) 10:S82-7. doi:10.1038/ $\mathrm{nm} 1141$

184. McDonald SM, Nelson MI, Turner PE, Patton JT. Reassortment in segmented RNA viruses: mechanisms and outcomes. Nat Rev Microbiol (2016) 14:448-60. doi:10.1038/nrmicro.2016.46

185. Petrova VN, Russell CA. The evolution of seasonal influenza viruses. Nat Rev Microbiol (2018) 16:47-60. doi:10.1038/nrmicro.2017.118

186. McCullers JA. The co-pathogenesis of influenza viruses with bacteria in the lung. Nat Rev Microbiol (2014) 12:252-62. doi:10.1038/nrmicro3231

187. Ballinger MN, Standiford TJ. Postinfluenza bacterial pneumonia: host defenses gone awry. J Interferon Cytokine Res (2010) 30:643-52. doi:10.1089/ jir.2010.0049

188. Short KR, Kroeze EJBV, Fouchier RAM, Kuiken T. Pathogenesis of influenzainduced acute respiratory distress syndrome. Lancet Infect Dis (2014) 14: 57-69. doi:10.1016/S1473-3099(13)70286-X

189. Abdul-Careem MF, Mian MF, Yue G, Gillgrass A, Chenoweth MJ, Barra NG, et al. Critical role of natural killer cells in lung immunopathology during influenza infection in mice. J Infect Dis (2012) 206:167-77. doi:10.1093/ infdis/jis340

190. Aldridge JR, Moseley CE, Boltz DA, Negovetich NJ, Reynolds C, Franks J, et al. TNF/iNOS-producing dendritic cells are the necessary evil of lethal influenza virus infection. Proc Natl Acad Sci U S A (2009) 106:5306-11. doi:10.1073/pnas.0900655106

191. Ivanov S, Renneson J, Fontaine J, Barthelemy A, Paget C, Fernandez EM, et al. Interleukin-22 reduces lung inflammation during influenza A virus infection and protects against secondary bacterial infection. J Virol (2013) 87:6911-24. doi:10.1128/JVI.02943-12

192. Pociask DA, Scheller EV, Mandalapu S, McHugh KJ, Enelow RI, Fattman CL, et al. IL-22 is essential for lung epithelial repair following influenza infection. Am J Pathol (2013) 182:1286-96. doi:10.1016/j.ajpath.2012.12.007

193. Barthelemy A, Sencio V, Soulard D, Deruyter L, Faveeuw C, Le Goffic R, et al. Interleukin-22 immunotherapy during severe influenza enhances lung tissue integrity and reduces secondary bacterial systemic invasion. Infect Immun (2018) 86(7):e706-17. doi:10.1128/IAI.00706-17

194. Barthelemy A, Ivanov S, Hassane M, Fontaine J, Heurtault B, Frisch B, et al. Exogenous activation of invariant natural killer $\mathrm{T}$ cells by $\alpha$-galactosylceramide reduces pneumococcal outgrowth and dissemination postinfluenza. MBio (2016) 7:e1440-1416. doi:10.1128/mBio.01440-16

195. Ussher JE, Bilton M, Attwod E, Shadwell J, Richardson R, de Lara C, et al. CD161++ CD8+ T cells, including the MAIT cell subset, are specifically activated by IL-12+IL-18 in a TCR-independent manner. Eur J Immunol (2014) 44:195-203. doi:10.1002/eji.201343509

196. Turtle CJ, Delrow J, Joslyn RC, Swanson HM, Basom R, Tabellini L, et al. Innate signals overcome acquired TCR signaling pathway regulation and govern the fate of human CD161(hi) CD $8 \alpha^{+}$semi-invariant T cells. Blood (2011) 118:2752-62. doi:10.1182/blood-2011-02-334698 
197. Gleimer M, von Boehmer H, Kreslavsky T. PLZF controls the expression of a limited number of genes essential for NKT cell function. Front Immunol (2012) 3:374. doi:10.3389/fimmu.2012.00374

198. Paget C, Trottein F. Role of type 1 natural killer T cells in pulmonary immunity. Mucosal Immunol (2013) 6:1054-67. doi:10.1038/mi.2013.59

199. Scheuplein F, Lamont DJ, Poynter ME, Boyson JE, Serreze D, Lundblad LKA, et al. Mouse invariant monoclonal antibody NKT14: a novel tool to manipulate iNKT cell function in vivo. PLoS One (2015) 10:e0140729. doi:10.1371/ journal.pone.0140729

200. Godfrey DI, Le Nours J, Andrews DM, Uldrich AP, Rossjohn J. Unconventional T cell targets for cancer immunotherapy. Immunity (2018) 48:453-73. doi:10.1016/j.immuni.2018.03.009

201. Bedard M, Salio M, Cerundolo V. Harnessing the power of invariant natural killer T cells in cancer immunotherapy. Front Immunol (2017) 8:1829. doi:10.3389/fimmu.2017.01829

202. Cerundolo V, Silk JD, Masri SH, Salio M. Harnessing invariant NKT cells in vaccination strategies. Nat Rev Immunol (2009) 9:28-38. doi:10.1038/ nri2451

203. Mak JYW, Xu W, Reid RC, Corbett AJ, Meehan BS, Wang H, et al. Stabilizing short-lived Schiff base derivatives of 5-aminouracils that activate mucosalassociated invariant T cells. Nat Commun (2017) 8:14599. doi:10.1038/ ncomms 14599

204. Li K, Vorkas CK, Chaudhry A, Bell DL, Willis RA, Rudensky A, et al. Synthesis, stabilization, and characterization of the MR1 ligand precursor 5-amino-6-D-ribitylaminouracil (5-A-RU). PLoS One (2018) 13:e0191837. doi:10.1371/journal.pone.0191837

205. Wakao H, Yoshikiyo K, Koshimizu U, Furukawa T, Enomoto K, Matsunaga T, et al. Expansion of functional human mucosal-associated invariant $\mathrm{T}$ cells via reprogramming to pluripotency and redifferentiation. Cell Stem Cell (2013) 12:546-58. doi:10.1016/j.stem.2013.03.001

206. Sheridan C. Allogene and celularity move CAR-T therapy off the shelf. Nat Biotechnol (2018) 36:375-7. doi:10.1038/nbt0518-375

207. Heczey A, Liu D, Tian G, Courtney AN, Wei J, Marinova E, et al. Invariant NKT cells with chimeric antigen receptor provide a novel platform for safe and effective cancer immunotherapy. Blood (2014) 124:2824-33. doi:10.1182/ blood-2013-11-541235

208. Tian G, Courtney AN, Jena B, Heczey A, Liu D, Marinova E, et al. CD62L+ NKT cells have prolonged persistence and antitumor activity in vivo. J Clin Invest (2016) 126:2341-55. doi:10.1172/JCI83476

209. Wykes MN, Lewin SR. Immune checkpoint blockade in infectious diseases. Nat Rev Immunol (2018) 18:91-104. doi:10.1038/nri.2017.112
210. Brown KE, Freeman GJ, Wherry EJ, Sharpe AH. Role of PD-1 in regulating acute infections. Curr Opin Immunol (2010) 22:397-401. doi:10.1016/j. coi.2010.03.007

211. Sharpe AH, Pauken KE. The diverse functions of the PD1 inhibitory pathway. Nat Rev Immunol (2018) 18:153-67. doi:10.1038/nri.2017.108

212. Patil NK, Guo Y, Luan L, Sherwood ER. Targeting immune cell checkpoints during sepsis. Int J Mol Sci (2017) 18:2413. doi:10.3390/ijms18112413

213. Biburger M, Tiegs G. Activation-induced NKT cell hyporesponsiveness protects from alpha-galactosylceramide hepatitis and is independent of active transregulatory factors. J Leukoc Biol (2008) 84:264-79. doi:10.1189/ jlb.0607352

214. Parekh VV, Wilson MT, Olivares-Villagómez D, Singh AK, Wu L, Wang C-R, et al. Glycolipid antigen induces long-term natural killer $\mathrm{T}$ cell anergy in mice. J Clin Invest (2005) 115:2572-83. doi:10.1172/JCI24762

215. Chang DH, Osman K, Connolly J, Kukreja A, Krasovsky J, Pack M, et al. Sustained expansion of NKT cells and antigen-specific T cells after injection of alpha-galactosyl-ceramide loaded mature dendritic cells in cancer patients. J Exp Med (2005) 201:1503-17. doi:10.1084/jem.20042592

216. Fujii S, Shimizu K, Kronenberg M, Steinman RM. Prolonged IFN-gammaproducing NKT response induced with alpha-galactosylceramide-loaded DCs. Nat Immunol (2002) 3:867-74. doi:10.1038/ni827

217. Macho-Fernandez E, Cruz LJ, Ghinnagow R, Fontaine J, Bialecki E, Frisch B, et al. Targeted delivery of $\alpha$-galactosylceramide to CD $8 \alpha+$ dendritic cells optimizes type I NKT cell-based antitumor responses. J Immunol (2014) 193: 961-9. doi:10.4049/jimmunol.1303029

218. Ghinnagow R, De Meester J, Cruz LJ, Aspord C, Corgnac S, MachoFernandez E, et al. Co-delivery of the NKT agonist $\alpha$-galactosylceramide and tumor antigens to cross-priming dendritic cells breaks tolerance to self-antigens and promotes antitumor responses. Oncoimmunology (2017) 6:e1339855. doi:10.1080/2162402X.2017.1339855

Conflict of Interest Statement: The authors declare that the research was conducted in the absence of any commercial or financial relationships that could be construed as a potential conflict of interest.

Copyright (C) 2018 Trottein and Paget. This is an open-access article distributed under the terms of the Creative Commons Attribution License (CC BY). The use, distribution or reproduction in other forums is permitted, provided the original author $(s)$ and the copyright owner(s) are credited and that the original publication in this journal is cited, in accordance with accepted academic practice. No use, distribution or reproduction is permitted which does not comply with these terms. 